\title{
Itinerario
}

http://journals.cambridge.org/lTI

Additional services for Itinerario:

Email alerts: $\underline{\text { Click here }}$

Subscriptions: $\underline{\text { Click here }}$

Commercial reprints: $\underline{\text { Click here }}$

Terms of use : $\underline{\text { Click here }}$

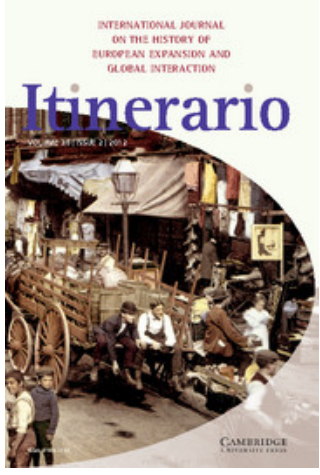

\section{Creating Confusion in the Colonies: Jews, Citizenship, and the Dutch and British Atlantics}

\author{
Jessica Roitman \\ Itinerario / Volume 36 / Issue 02 / August 2012, pp 55 - 90 \\ DOI: 10.1017/S0165115312000575, Published online:
}

Link to this article: http://journals.cambridge.org/abstract_S0165115312000575

How to cite this article:

Jessica Roitman (2012). Creating Confusion in the Colonies: Jews, Citizenship, and the Dutch and British Atlantics. Itinerario, 36, pp 55-90 doi:10.1017/S0165115312000575

Request Permissions : $\underline{\text { Click here }}$ 


\title{
Creating Confusion in the Colonies
}

\author{
Jews, Citizenship, and the Dutch and British Atlantics
}

JESSICA ROITMAN*

Jews in most of early modern Europe struggled to assert their rights within legal frameworks that presumed them to be intrinsically different-aliens-from the (Christian) population around them no matter where they had been born, how they dressed and behaved, or what language they spoke. This struggle played itself out on various fronts, not the least of which was in the Jewish assertion of the right to become more than aliens - to become citizens or subjects - of the territories in which they lived. Citizenship, in its various forms, was a structural representation of belonging. Moreover, citizenship conferred tangible rights. As such, being a recognised citizen (or subject) had not only great symbolic, but also great economic, importance.

This recognition of belonging was needed for, among other things, Jewish participation in the settlement and economic exploitation of the Dutch and British Atlantic overseas' possessions. And, it should be noted, it was really only in the British and Dutch Atlantics that Jews could settle openly until the nineteenth century. ${ }^{1}$ Therefore, Jews in the Dutch and British Atlantic engaged in a complex and long-running assertion of their rights as subjects or citizens with metropolitan governments, colonial administrators, and non-Jewish settlers. ${ }^{2}$ This assertion of rights involved employing the language of legality and loyalty, as well as demanding the opportunity to fulfil duties such as serving in the civil militias, in order to emphasise the reciprocity of obligations. These same governments, administrators and settlers were involved in often divisive discussions of how these Jews fit into their own understandings of what it meant to be a citizen or subject. This article will argue that Jews scrambled ideas of "national" allegiances and were active agents in the negotiation of citizenship rights across imperial boundaries. Furthermore, I argue that by studying the case of the Jews in the Dutch and British Atlantic in the early modern period, we can revisit and rethink ideas of national belonging and exclusion during a time of great fluidity - a time when categories of identity were being shaped by political, economic, and cultural conditions much different from what came before or after. ${ }^{3}$ 


\section{Jews and Citizenship in the Dutch Republic and England: Background and Theory}

Generally, Jews were not allowed citizenship in medieval Europe, a situation that continued into the early modern period. Jews were usually viewed as aliens who were tolerated, but within relatively firm boundaries restricting their cultural, religious, and economic practices. This varied from territory to territory and, for example, Jews in some parts of Poland were allowed rights similar to those of many citizens. ${ }^{4}$ And in Germany, the legal position of Jews varied greatly based on local conditions. Be that as it may, the fact remains that the legal status of Jewish populations remained uncertain, at best, throughout most of Europe until the end of the early modern period.

Within the Dutch Republic and England, the status of Jews had not been an issue because there were next to no Jews in these territories until the very end of the sixteenth century, when Sephardic Jewish merchants began to arrive in Amsterdam and London, ostensibly as Portuguese Catholics. The Sephardim had gone to the Habsburg Netherlands, particularly Antwerp, in the mid-to-late sixteenth century thanks to its central role in the handling and distribution of Portuguese and Spanish colonial products. By 1570, there were around 400 New Christians living in Antwerp, but open Jewish settlement was prohibited. ${ }^{5}$ It was not allowed in the Northern Netherlands either until the rebellion of these seven northern provinces against the Habsburg monarchy. When Antwerp fell to Habsburg forces in 1585, immigrants, including New Christians, fled to the northern provinces where some eventually lived openly as Jews. At the same time, many Protestant immigrants left Antwerp in search of religious freedom. However, many (if not most) of these immigrants, both Protestants and the Portuguese New Christians, came to the Dutch Republic, particularly Amsterdam, to take advantage of the emerging economic opportunities, especially in colonial trade.

In contrast to the Low Countries, which had never had a settled Jewish community of any size, the English had expelled their large and vibrant Jewish community in 1290. A small number of Spanish and Portuguese New Christians resided in London from the late Middle Ages. ${ }^{6}$ In the early part of the seventeenth century, Sephardim were attracted to London due to its growing importance in international commerce, though they were required to continue living outwardly as Catholics. Estimates vary, but there were possibly as many as fifty to a hundred Sephardim in London before the de facto re-admission of Jews to England in 1656. ${ }^{7}$ The Sephardim of continental Europe under the leadership of Manasseh ben Israel of Amsterdam, and with the help of New Christians already resident in London, petitioned Oliver Cromwell for the readmission of the Jews to England. ${ }^{8}$

Many English Protestants at the time were millenarians who believed in the imminent "Second Coming of the Messiah" which would not be possible until the conversion of the Jews. To speed this conversion of the Jews and, thereby, the Second Coming, many clergymen and theologians believed that it was necessary to bring them to England. The English could, it was argued, show them the pure Protestant faith instead of Iberian popery-a demonstration that would be sure to convince the Jews of the error of their ways. ${ }^{9}$ Under the influence of this millenarian thought, as well as economic arguments in favour of the Jews' utility, Cromwell convened what 
became known as The Whitehall Conference to consider ben Israel's petition. ${ }^{10}$ Though there was no final resolution resulting from the conference, nor was there a revocation of the original thirteenth-century order of expulsion, there was an informal recognition that there were no legal grounds for keeping Jews out of England, and this lessened objections to the open presence of Jews.

But because there had never been any official readmission, the legal status of Jews in England remained uncertain. This uncertainty meant that subsequent English governments could-and did-impose various restrictions on the kinds of activities in which Jews could engage. ${ }^{11}$ For instance, merchants could not open retail shops within the City of London without being so-called "freedmen." However, becoming a freeman of the City meant taking a Christian oath, which effectively shut all Jews out. ${ }^{12}$ Moreover, admission to the monopoly trading companies, the Russia and Levant companies, in particular, was limited for Jews, and the commodities exchange in London restricted the number of Jewish brokers to twelve until 1830. ${ }^{13}$ Jews could not sit in Parliament or vote in parliamentary elections, hold office in a municipal corporation, "occupy a place of trust under the Crown" (essentially work as a civil servant), or attend university.

These limitations on economic activities were indicative of the second-class status under which Jews operated, even if they were born in Britain and, therefore, were officially British subjects. However, by the mid-eighteenth century, around half of Jews living in Britain had not been born there, and the legal disabilities that weighed most heavily on Jews had less to do with religion per se than with their being foreign-born aliens. ${ }^{14}$ Because they were aliens, they could not hold land or property while the Navigation Acts prohibited them from, owning shares in British ships. Foreign merchants were forced to pay "alien duties" which included special port fees and higher customs rates on many commodities-rates that were sometimes twice as high as those on native merchants. ${ }^{15}$ But it was not possible for Jews to become naturalised in Britain because naturalisation required a special act of Parliament. This was one of the pieces of "accidental" discriminatory legislation that was initially aimed at Catholics; and the petitioner had to receive the sacrament of the Church of England before the bill of naturalisation was introduced. Because naturalisation was all but impossible for Jews in Britain to obtain, the only option was denization, which involved securing a costly letter (royal patent) granted to an individual by the monarch on the advice of his council. Denizens could engage in colonial trade, but denization was not retrospective, so a denizen's foreign-born children remained aliens and could not inherit his property. ${ }^{16}$ Moreover, denization did not grant exemption from alien duties, and a denizen could not hold office. ${ }^{17}$

Throughout the seventeenth century, these two methods of becoming an English subject operated simultaneously. As J.M. Ross points out, naturalisation offered more rights, but it was more cumbersome because Parliament sat infrequently, whereas the bureaucracy for issuing a letter patent operated continuously. ${ }^{18}$ Letters patent granted to Jews often included a proviso that the grantee "shall not have nor enjoy any benefit or advantage from the said grant of our denization until he shall have taken the oath of allegiance." ${ }^{19}$ The second point relates to the Customs duties on exports. From about 1630 patents of denization almost always included a condition requiring that the grantee shall "pay to us and to our heirs and successors custom and subsidy for his goods and merchandise at the rates which aliens pay or 
ought to pay."20 Exceptionally, some (but by no means all) Jews made denizens by Charles II and James II were not subjected to this standard condition; some were even specifically exempted from it. ${ }^{21}$ Despite these exceptions, however, there seem to have been little difference between being an alien and being a denizen in terms of the alien duties, though, crucially, there was a difference in terms of inheritance. Thus, as James Shapiro writes, "The status of aliens was made up of a patchwork of overlapping and sometimes conflicting jurisdictions."22

However, in 1740 legislation was passed that allowed foreigners who had resided for seven years in the American colonies to naturalise without a bill in Parliament, an effort clearly designed to encourage trade and colonisation in the Americas. ${ }^{23}$ All that was required was that the applicant make a declaration of fidelity and pay a fee of two shillings to the office of the secretary of the particular colony in which he resided. In return he was granted a certificate which served as a complete naturalisation paper. ${ }^{24}$ Jews and Quakers were exempted from the oath of abjuration and from receiving the sacrament. ${ }^{25}$ This so-called "Plantation Act" was of little benefit to Jews living in Britain itself, and Jews in the British Atlantic colonies had more flexibility and greater rights than those in the metropole. ${ }^{26}$

The Jews living in the Dutch Republic and Dutch Atlantic territories laboured under similar legal disabilities as those in Britain and her colonies, and their status as citizens was undefined. This uncertainty stemmed from the fact that, at least in a formal sense, there was no Dutch citizenship. Until 1795, citizenship was largely a local and urban institution conferred by birth or acquired by purchase, and probably no more than half of the urban population were formal citizens of the many cities and towns of the country. ${ }^{27}$ In this respect, the Dutch Republic differed little from the rest of Europe, as municipally-based citizenship was the norm in most of Europe, where formal citizenship status was at the core of the urban polity.

Urban citizens could count on judicial, economic, political, and social rights. Only citizens had a direct entrée into political power by serving in major municipal functions, and all the local councillors were citizens..$^{28}$ In the Dutch Republic, local affairs, as represented by the councillors, also tended to be provincial affairs, which in turn had an important impact on national affairs. Therefore, having a say in local affairs, especially as a member of the city council, was of great political importance. ${ }^{29}$ There were other clear advantages to holding formal citizenship, as well. Foremost of these was entrance to the guilds, which held a monopoly in the production of, and trade in, many or most goods and services. But not all trades were organised in guilds. In Amsterdam the trade in sugar, diamonds, and tobacco were outside the guild structure in the seventeenth and eighteenth centuries - all trades in which, not coincidentally, Jews came to dominate. This structure also meant, ultimately, that a significant part of the labour market was available for non-burgers in Amsterdam. ${ }^{30}$

This relative flexibility in the labour market meant that the position of the "inhabitants" (ingezetenen) or resident non-citizens in Amsterdam, as well as in most Dutch cities and towns, was not so bad. The municipalities gave their non-citizen residents the same protection under the law that their citizens had, including property rights. ${ }^{31}$ Hence, as historians Maarten Prak and Jan Luiten van Zanden argue, "Formal citizenship is merely one, albeit arguably the most significant, among a range of statuses embodying elements of citizenship." ${ }^{32}$ The Jews straddled sever- 
al categories along this spectrum of citizenship statuses on the Dutch Republic, specifically in Amsterdam.

Jews were admissible as burghers in Amsterdam, but with various restrictions placed upon them, as was the case for Jews in Britain. In Amsterdam there was only one clause in the various charters regarding citizenship which concerned religion, and this related to the Jews. ${ }^{33}$ In fact, the only exception to the general rule that all citizens of Amsterdam were equal was the Jews. Nevertheless, the presence of Jews, and the exercise of their religious practices, was accepted and to some degree celebrated. The well-known political economist, Pieter de la Court, lauded Amsterdam, where

Next to the freedom to worship God comes freedom to make one's living for all inhabitants. Here [in Amsterdam] it is very necessary to attract foreigners. And although this is of disadvantage to some old residents who would like to keep the best solely for themselves and pretend that a citizen should have preferences above a stranger, the truth of the matter is that a state which is not self-sufficient must constantly draw new inhabitants to it or perish. ${ }^{34}$

In line with this approach of economic utility, the community was allowed to organise itself, religiously and socially. Both the Sephardim and, later, the Ashkenazi Jews, could hold their own worship services and build their own synagogues. ${ }^{35}$ Nevertheless, the boundaries of their community were sharply drawn and strictly guarded. Intermarriage with, and conversion of, Dutch subjects were not allowed, and they had no claim on common poor relief, being obliged, instead, to care for their own poor. ${ }^{36}$ In addition to these restrictions, in 1632 , it was decided that Jews could not enter the guilds. ${ }^{37}$ There was a separate Jewish citizenship oath, which was in Portuguese, and this restriction was stated in the oath. It was also stated that citizenship could not be passed on to the children and that, therefore, Jews must purchase their citizenship anew in each generation. ${ }^{38}$

This was in contrast to Britain, which allowed those born on British soil to be subjects and to pass such rights on to their children, even if they were Jews. Nevertheless, as David Katz notes, the Anglo-Jewish community, despite the endenization of some of its leading figures, was neither alien nor citizen. ${ }^{39}$ And this comparison with Britain raises the question of whether the legal status of Jews in the Dutch Republic was different from that of other dissenters. In Britain it was not. Essentially, Jews and dissenters suffered under the same restrictions. Historian Peter van Rooden believes that initially the treatment of the Jews was different from that of other dissenters in the Dutch Republic, but that over time it ceased to be. However, van Rooden argues that this was not the result of a change in the way that Jews were treated. On the contrary, he asserts that the policies towards other dissenting groups became more like those that had always governed Jews." 40

Despite the fact that the legal status of the Jews was similar to that of Christian dissenters in both countries, there was a clear difference in how Jews were perceived vis-à-vis dissenters. A typical view expressed in mid-eighteenth century Britain was that of Sir Edmund Isham, a Tory MP who drew a distinction between Jews and other would-be immigrants in a speech to the House of Commons: 
...the Jews are not like French [Huguenot] refugees, or German Protestants: these in a generation or two become so incorporated with us, that there is no distinguishing them from the rest of the people: their children or grandchildren, are no longer French or German or of the French or German nation, but become truly English, and deem themselves to be of the English nation. But...Jews can never be incorporated with us: they must forever remain Jews, and will always deem themselves to be of the Hebrew not the English nation. ${ }^{41}$

For Isham, Jews were simply unassimilable and their presence in Britain or her colonies was therefore unwelcome. Analogous debates in the Dutch parliament show how deeply ingrained ideas of Jewish "strangeness" actually were, even into the nineteenth century - the point at which Jews were supposedly fully "emancipated" and, thereby, completely incorporated into the Dutch nation. As late as 1873, a representative in the Lower House of the Dutch Parliament, Johannes Haffmans, said of the Jews, "They are strangers here. We [Catholics] are at home here." ${ }^{42}$ For Haffmans, the unassimilability of the Jews was their essential difference from Christians, even Catholics who had once laboured under laws even more discriminatory than those targeting Jews.

Charles Tilly quite rightly states that "the word citizenship causes confusion." ${ }^{43}$ This confusion is caused, in part, by the fact that citizenship can have so many gradations, as was the case of the Jews (and other groups) in early modern Britain and the Dutch Republic. These gradations, in turn, implied many different levels of belonging because, as Tilly writes, "As a category, citizenship designates a set of actors-citizens-distinguished by their shared privileged position vis-à-vis some particular state. As a tie, citizenship identifies an enforceable mutual relation between an actor and state agents. As a role, citizenship includes all of an actor's relations to others that depend on the actor's relation to a particular state. And as an identity, citizenship can refer to the experience and public representation of category, tie or role." ${ }^{44}$ In the case of the Jews, the multiple, and often confusing, meanings of citizenship so clearly expressed by Tilly - a category, a tie, a role, and, most of all, an identity-created a discomfort that is nowhere more evident than during the early modern period.

Although diatribes such as those given in their respective parliaments by Isham and Haffmans could-and were-voiced against other outsiders, they were most often specifically targeted at Jews. As Frank Felsenstein argues, "[The Jew] is the perpetual outsider whose unsettling presence serves to define the bounds that separate the native Englishman from the alien Other." 45 This dichotomy was likely less sharply drawn in the Dutch Republic. Nevertheless, there was a clear popular understanding of the Jew as an unsettled and possibly unsettling Other within the Dutch imagination. Popular Dutch pamphlets from the seventeenth and eighteenth centuries emphasise the seemingly intrinsic difference between (Christian) Dutch men and women and Jews. As early as 1603 when there were, at best, only a handful of Jews in the Dutch Republic, and what Jews there were nearly all lived in Amsterdam, a pamphlet was published, in which the Bishop of Schleswig purportedly claimed to have met the wandering Jew, Ahasuerus. All the tropes about Jews that would later become so familiar-no fixed abode, continually punished for the 
betrayal of Jesus, a usurious nature and prone to criminality-appear in this pamphlet. ${ }^{46}$ Jews were also popular subjects of ridicule for their accents (especially the Yiddish-speaking Ashkenazim), their manners, and their professions. ${ }^{47}$

This continued assertion of the otherness and unassimilability of Jews demonstrates the sharp distinction between "us" and "them" that was central to the formation of early modern communities, and, by extension, early modern conceptions of citizenship. This is because citizenship in the early modern period was, in addition to Tilly's formulation, an instrument of social regulation. ${ }^{48}$ As a category of belonging that endowed people with specific rights and duties, citizenship allowed for the drawing of boundaries and distinctions between those who belonged and those who did not. By its nature, the status of citizen created juridical, political, economic, and social bonds between the individual and the state. ${ }^{49}$

It was this creation of social bonds and the recognition of shared belongingTilly's citizenship as identity - that created the most unease with regard to the Jews. But being a recognised citizen (or subject, in the case of the British) had not only great symbolic but also great economic, importance. ${ }^{50}$ Thus, it was most often in the economic sphere that anxieties about what it meant to include Jews in the shared community played themselves out. This was nowhere more visible than in Jewish participation in the settlement and economic exploitation of the Dutch and British Atlantic overseas' possessions. The next section will discuss how the discomfort with including Jews in the colonial enterprise manifested itself in the Dutch and British Atlantic settlements.

An abundance of such settlements scattered over a vast region offer numerous cases to draw upon. I have centred my discussion on cases of discrimination against Jews in Curaçao (and, briefly, Suriname) and Jamaica when there were also numerous incidents in Barbados or the North American settlements. ${ }^{51}$ And despite a surfeit of information, I have not discussed the unique case of New Holland (Dutch Brazil) at all. ${ }^{52}$ There is, admittedly, a certain arbitrariness implied by my choices. However, due to the constraints of time and space, I have had to limit my discussion to a few illustrative examples to prove my point.

\section{Questions of Belonging: Contested Citizenship in the Colonies}

Both the British and the Dutch government (Company) officials actively encouraged Jewish settlement in their Atlantic colonies-settlement that was loosely guided by and based upon regulations regarding Jewish rights to reside in the metropole, as described above. However, non-Jewish settlers and, often, colonial administrators, were frequently unwilling to fully accept Jews into their respective folds. This difficulty centred on the navigation between the economic imperatives of empires, as dictated from the metropole and carried out by locally-based colonial administrators, on the one hand, and deeply ingrained ideas of what it meant to belong-or not-as part of an economic and socially constructed community. After all, Jews were not only deft economic competitors, but the unassimilable "Other." All of which resulted in a patchwork of sometimes conflicting regulations and attitudes regarding Jews in the British and Dutch colonies. 


\section{Belonging in the English Atlantic-Discrimination in Jamaica}

Take, for instance, the case of the Jews in the British colony of Jamaica. This island was initially under-populated, and it was official policy to attract settlers by dispensing with oaths of allegiance and offering freedom of religion..$^{53}$ In instructions dated December 31, 1670, Sir Thomas Lynch, Lieutenant-Governor of Jamaica, was ordered to give all possible encouragement to persons of differing religions by dispensing with the oaths of allegiance and supremacy (except to officials of the Council) and "finding some other way of securing allegiance," and he was to suffer no man "to be molested in the exercise of his religion, so he be content with a quiet and peaceable enjoying of it." ${ }^{54}$ In July of 1672, the council wrote that "for the better settling and improving of your Majesty's Island of Jamaica, due encouragement may be given to the Jews, the Dutch, and other nations to settle and inhabit there." 55

Thus, in the furtherance of imperial economic objectives during the seventeenth and eighteenth centuries, colonial governors were expected to tolerate Jews, allow them to worship publicly and to practice their religious rites and traditions. "They observe most of their ancient feasts and fasts," noted one member of the Jamaican elite, "marry, circumcise, and bury according to the custom of their forefathers." This despite the fact that the Jews were suspected of conniving with the enemy and with any other non-English people. As one complaint went, "If the Spanish had the courage they could take the island [of Jamaica]. The island is inhabited by English, Scots, Irish and Jews. Two-thirds are not loyal to the government. They might prove a broken reed if attacked." ${ }^{57}$ But by the passage of the Naturalization Act of 1740 , authorised over the objections of island legislature, the colonial governors were expected to do more than just tolerate the Jews. ${ }^{58}$ This act made lawful the naturalisation of Jews-but not Catholics-by individual colonies.

Although Jamaican officials did permit the naturalisation of Jews, other colonies were more reluctant, and the act certainly did not put a stop to discrimination. In a celebrated case, the prominent Jewish merchants Aaron Lopez and Isaac Elizur of Newport, Rhode Island, were denied naturalisation in 1761 and $1762 .{ }^{59}$ In Rhode Island, "Jews were promised only such "protection here as any strangers being not of our nation residing amongst us'."60 This ruling illustrates the fact that Jews were viewed first and foremost as strangers and as manifestly alien. That being said, Lopez and Elizur were relatively easily able to circumvent Rhode Island's discriminatory ruling by going to nearby colonies where they were naturalised. Elizur went to New York and was naturalised in 1763 and Lopez went to Massachusetts, where he was naturalised in Boston in 1762. They then returned to Newport where they could now enjoy the full advantages of citizenship. ${ }^{61}$ Although citizenship could be denied in various places, subject to the whims of colonial administrators, once someone was naturalised, his naturalisation was meant to be applicable everywhere.

Despite some discomfort with what James Shapiro describes as "...the especially pernicious...Jewish Other that kept trying to claim for itself a part of Englishness ...," ${ }^{2}$ the 1740 act, as various scholars have remarked, gave (professing) Jews in the British colonies of the Atlantic "an unprecedented forum for the expansion of Jewish rights of citizenship." ${ }^{63}$ Lois Dubin has claimed that the particular circumstances of the British Atlantic colonies resulted in greater "relaxation and renegotiation" of political and religious conventions in comparison with the metropole. ${ }^{64}$ Yet 
passage of this act did not significantly challenge the position of Jews as social outsiders in Jamaica (or the rest of the British colonies). Notwithstanding their right to be naturalised as British subjects, most Jews were thought to be "selfish and tricking," as well as "fraudulent in their trade," and most certainly not truly British. ${ }^{65}$

Though there was some uneasiness with Jews, and anti-Jewish stereotypes endured within the popular imagination, Jews were still allowed many of the privileges of other white colonists, including trading in and owning slaves. ${ }^{66}$ On Barbados and Jamaica, Jewish planters owned slaves, though never a large proportion of the total slave population on the islands, which is line with the fact that there were relatively few Jewish planters. Just like other white colonists, Jews bought slaves for resale and redistribution (so-called "refuse slaves") in the inter-Caribbean transit trade. ${ }^{67}$ Eli Faber demonstrates that Jewish investment in the Royal African Company (RAC) reached its peak in the mid-1690s and lasted until the second decade of the eighteenth century. ${ }^{68}$ During this time, the RAC accounted for around 20 per cent of the English slave trade, and Jews owned about 10 per cent of RAC shares. ${ }^{69}$

Generally, Jewish involvement in the slave trade in the eighteenth century fluctuated with the vicissitudes of the Atlantic economy. Only in two British colonies did Jewish participation in the slave trade rise above the approximately 6 to 7 per cent that had been the norm for Jewish involvement in the seventeenth century. ${ }^{70}$ This Jewish participation in the slave trade has been a topic of vociferous debate in the past two decades. ${ }^{71}$ This debate emerged despite the fact that Jews, either openly professing Jews or those of Jewish descent such as New Christians, participating in the slave trade had long been known and acknowledged. ${ }^{72}$ Within the context of this discussion, what is most important to note about this Jewish involvement in the ownership of and trade in enslaved Africans is that it was proportionate to that of other white, non-Jewish, colonists.

Though in this vital element of life in the British Atlantic colonies Jews were more or less equal to non-Jews, in the same year that parliament allowed for the naturalisation of Jews in most of the colonies and thereby put them on an equal footing with non-Jews, the Jamaican Assembly asserted that Jews controlled too much of the island's commerce and "have almost entirely engrossed the whole retail trade of this island." 73 Jews were, therefore, "a great growing evil" who were driving the Christian citizenry from their trades and literally taking bread from the mouths of their children, a grievance that was repeated throughout the islands. ${ }^{74}$ As C.S. Monoco notes, "Colonists felt greatly impeded in what they saw as their natural right: returning to England as wealthy men (and as rapidly as possible)." ${ }^{75}$ Monoco goes on to explain that disparities between local Caribbean interests and the metropole become imperative in contextualising the broad array of measures taken against Jews on the British islands. ${ }^{76}$

Naturalisation was hotly debated in Britain-a debate which culminated in the so-called "Jew Bill" of 1753, which has been discussed at great length in many fine studies of Anglo-Jewry. ${ }^{77}$ Therefore, I will only briefly summarise it here. The fairly modest goal of this bill was to allow foreign-born Jews who had lived at least three years in either Great Britain or Ireland to be naturalised as British subjects by a private petition to Parliament without having to take the Anglican sacrament. As aliens, foreign-born Jews could not hold land or property, had to pay up to twice as much 
duty on imports (until alien duties were abolished in 1784), could not own British ships, and could not act as factors or merchants in the colonial trade. ${ }^{78}$ The law's procedures were expensive, complicated and intended only for a small group of wealthy Sephardic merchants. The ultimate goal of the bill was to further the nation's economic prosperity, which was thought to be advanced by encouraging the immigration of more wealthy Sephardic traders, who would be more likely to come to Britain if they could easily naturalise. What resulted from this bill was an ocean of pamphlets both pro and con. Most pamphleteers who inveighed against the naturalisation of Jews believed that Jewish immigrants would ultimately unravel the fabric of British society. ${ }^{79}$ Or as one writer put it, the consequence of naturalising the Jews will be "our own Destruction as a people." 80

This pervasive belief in the destructive nature of Jewish colonists spawned local anti-Jewish legislation that led to disproportionate taxation, restrictions on the right to testify in court, and impeding access to valued trading licenses, among other limitations. ${ }^{81}$ Laws passed in Jamaica were often designed to be as offensive as possible to Jewish residents, including an act that grouped "convicts, Jews...sick, decripped [decrepit], or disabled persons" as a pariah class. ${ }^{82}$ Edward Long, the oftquoted, eighteenth-century historian of Jamaica, noted that even those Jews who had undergone the expensive and lengthy process of naturalisation were effectively on an equal footing with free blacks because both groups shared an almost identical social stigma and "limited freedom" and could neither vote nor hold elected office. ${ }^{83}$ Not surprisingly, then, the minutes of the meetings of the Jamaican assembly are chock full of calumnies against Jews and record many (unsuccessful) attempts, in the form of petitions to the king, to remove Jews from the islands completely for, among other reasons, being descended from the crucifiers of Jesus." ${ }^{84}$

Holly Snyder rightly frames these discriminatory acts as part of an attempt to keep "undesirable" groups including Jews, freed Blacks, Catholics, Quakers, and those of mixed race from taking part in local politics or in any other way threatening the existing political hegemony of Englishman over their non-English compatriots. ${ }^{85}$ But they also illustrate the difficulties in conceptualising the idea of Jews as English full stop. Tamar Herzog writes that "Naturalization allowed [people] to truly transform themselves by abandoning the natural allegiance to their community of birth, and by adopting a new nature...Citizenship was not only a civil institution established by the community but also an institution that changed the nature of people." ${ }^{86}$ But the colonists of Jamaica were not sure that Jews could ever abandon their natural allegiance to "the Hebrew nation" and change their (assumedly unassimilable) nature.

This was an accusation that Jews in England addressed directly in a petition entitled The Case of the Jews Stated which was written in 1689 as an appeal against a bill for special parliamentary taxation of the Jews. In this document they claim that the very fact that they are "homeless" as a nation makes them better and more desirable subjects. They write "that the Jews being a nation that cannot lay claim to any country do never remove from any part where they are tolerated and protected. And therefore may be looked upon to be a greater advantage to this kingdom than any other foreigners, who commonly, so soon as they got good estates, return with them into their own countries." ${ }^{87}$ The Jews were also anxious to disavow any ideas the English government or public might have had of a worldwide unity of "the 
Hebrew Nation," if for no other reason than to discourage further attempts at extra taxation based on the (mistaken) belief that Jews in other lands would pay. Later in the petition they explicitly state,

Whereas the Jews are informed that there is a rumour goes about, That what these who are not able to pay, the Jews in other Parts will make up, looking upon them all to make but one Body, though at never so great a distance from each other: They humbly take leave to represent, that in Truth every one particular Man among them subsists of himself, without dependence on any other; And that they cannot expect any Assistance, or Relief from any other place whatsoever. ${ }^{88}$

This petition makes clear that the Jews in England were beginning to base their arguments for rights upon their utility and their loyalty, which is a pattern that would grow ever stronger in both the British and Dutch Atlantic territories in the following century.

\section{Belonging in the Dutch Atlantic-Discrimination on Curaçao}

In contrast to the English, naturalisation as a topic seems to have raised little debate in the Dutch Republic, perhaps because it was already officially necessary to naturalise if one moved to a different province within this loose confederation. That meant that there tended to be little in the way of overarching identity attached to the procedure.$^{89}$ It was, largely, a pro forma procedure in the Dutch Republic. In keeping with this approach, neither the province of Holland nor the States General of the United Provinces ever promulgated what could really be said to be a uniform policy toward Jews in general or to their naturalisation specifically. This was not surprising given the rather fractured nature of the Dutch polity. One of the only statements that can be defined as a policy towards the Jews as such was issued by both the States of Holland and the States General in 1657. This declaration stated that Jews were "subjects" of the Dutch Republic, and was issued over and against the seizures of Jewish-owned ships and cargoes by the Spaniards. ${ }^{90}$ Though the Jews were, therefore, declared to be subjects (despite the lack of a monarchy) of the Dutch Republic, individual cities were allowed to decide whether they wanted to admit Jews, the only proviso being that cities and towns that did choose to admit them could not compel Jews to wear any distinguishing marks. ${ }^{91}$

As had been the case in Jamaica and other British Atlantic colonies, the Dutch West India Company (WIC) had a clear policy of encouraging immigration to its Atlantic territories, including the immigration of Jews. To take just one example, Governor Jacob Beck advocated free immigration to Curaçao. He informed the WIC directors, "Since the island depends on commerce for its existence and that is what brings in and augments your income, any stranger, no matter of what nationality is encouraged and received decently by me so that he will settle here." 92 In general, the rights granted to Jews in the Dutch colonies in the Americas gave them unprecedented privileges. They could retain their separate communal autonomy, yet could claim, in effect, to be naturalised citizens of the Netherlands. Historian Hayim Yerushalami even believes that the Jews "had arrived at the closest point to full legal equality possible for Jews prior to the emergence of the modern nationstate." 93 
Yerushalami was writing about Curaçao, but it was Suriname that was best known for the privileges offered to Jews, thanks to the famous Essai historique in which Sephardic Jew David Nassy goes to great lengths to praise the situation of the Jews in this Dutch colony. Nassy writes that "there is perhaps no other place in the world where religious tolerance is more extensive and more strictly observed, without there ever having been any discussion or controversy whatsoever, than in Surinam." ${ }^{94}$ Jewish community leaders were able to exert extensive control over the community, including exiling members; Jewish marriages were considered legitimate even without a civil equivalent; Jews were allowed to serve in the civil militias; and Jewish slaves could work on Sundays. ${ }^{95}$

Yet despite these rights and privileges resulting from an officially-sanctioned desire for settlers in the Dutch Atlantic colonies, the reality of a Jewish presence in these territories caused unease on the part of other settlers, WIC functionaries (both local and in the metropole), Reformed clergy, and government officials. When it came to the rights and privileges that Jews would enjoy in the Dutch Atlantic colonies, this unease played itself out in the same sort of gap between official policy and actual practice that was so evident in the British Atlantic colonies. For example, Jews in Surinam could not be elected to the court of police nor exercise any public office other than that of notary and assistant tax collector. ${ }^{96}$ Nor were Jews appointed to most positions within the colonial government, and no Jews served on the ruling policy council. ${ }^{97}$ Jews on Curaçao could not vote at all for the ruling council of Curaçao, whereas in St. Eustatius, as in Suriname, they could take part in the elections, but not serve on the ruling council itself. ${ }^{98}$ Thus, the Jews (mostly Sephardim until the later part of the eighteenth century), within a seemingly uniform Dutch Atlantic world faced a range of challenges and were welcomed in some places and not in others. ${ }^{99}$

It is not surprising that Yosef Kaplan characterises as "rigid and even hostile" the attitude adopted by authorities on Curaçao toward the Jewish minority. ${ }^{100}$ There were complaints by non-Jewish residents objecting to competition from Jews. There were also intermittent attempts to limit the economic and political freedoms of Jews on the island. These attempts were as likely to come from WIC officials as they were from other settlers. And these challenges to Jewish rights on Curaçao do call into question historian Wim Klooster's statement that "even unofficial antiSemitism seems to have been a rare phenomenon" on Curaçao. ${ }^{101}$

In fact, the first half of the eighteenth century was rife with discriminatory actions against the Jews actively encouraged, if not instigated, by WIC officials. ${ }^{102}$ As had been the case on Jamaica, in 1713 the governor and island council insisted that the Jews should be taxed as a group and that the parnassim should be held responsible for ensuring the payment of the special levy - a stipulation that was not placed on Protestants. ${ }^{103}$ Moreover, in 1717 the island council refused to admit the oath "on the Law of Moses" of a Jew, Isaac de Moises Henriquez Cothinho, who was accused of insulting non-Jews. He languished in prison for ten months before his oath was finally admitted. ${ }^{104}$ When this same ill-fated Cothinho was murdered by three Frenchmen in 1720, the fiscaal (prosecutor) van Bergen was strongly suspected of letting the killers escape to Martinique, and when the Jewish community complained to the council, they were ordered "not to protest but to obey." 105

And, as in Jamaica, standard calumnies about Jews were commonly uttered in 
public and during island council meetings. In 1727, at a gathering called by the Governor Du Fay to increase import duties to cover the costs of building a hospital on the island, council member Frederick Eck warned that the Jews would be "resorting to trickery and not pay." At this same contentious meeting, another prominent colonist called the Jews "damned smonches" who dealt with the Spaniards illegally. The situation escalated from name-calling to physical threats when someone shouted "Let's fall upon the Jews and throw them over the wall". Eck subsequently complained that Jews were in control of the island's shipping and that they were privateers. ${ }^{106}$ When the Jewish community protested, Governor Du Fay echoed Eck's grievance when he wrote to the WIC council that "The Jews should not be allowed to come out triumphant, particularly since business is in their hands." ${ }^{107}$ All these complaints repeat the usual slurs directed at Jews as the tricky businessmen, smugglers, and monopolisers of trade.

This defamation is, perhaps, not particularly surprising given that Jews comprised a rather large percentage of the white European population in the Dutch Atlantic colonies. Estimates vary as to the exact number of Jews and the precise percentage of the white population they comprised. According to the foremost historians of the Curaçoan Jewish community, Suzanne and Isaac Emmanuel, Curaçao's total population in 1785 was 8,500 , of which 3,000 to 3,200 were white and around 1,200 of these whites were Jews. In other words, close to forty percent of the white population of the island was Jewish. ${ }^{108}$ Wim Klooster examines the population of Jews in Willemstad, Curacao's capital and major city, and estimates that by the middle of the eighteenth century, the number of Jewish families was nearly half that of white non-Jews. Based on WIC tax records, Klooster believes that by 1789 there were about 6,000 free residents in Willemstad, which included free blacks and "coloureds", most of whom were Catholics, as well as 2,469 Protestants and 1,095 Jews. ${ }^{109}$ Whatever the exact numbers, the Jews were quite visible in the economic and social life of the island at a time when their actual status as citizens, both in the colonies and in the Republic itself, remained somewhat undefined.

This indefinite legal and social status contributed to the continued vilification of Jews on the island in the following decades. Governor Du Fay's replacement, Governor van Collen, and his fiscaal van Schagen, wrote frequently to the WIC governing board in the Dutch Republic, saying, among other things, that there were "seven Jews to one Christian" and "like the Jesuits they were taking over." They even asserted that Jews accounted for almost three-quarters of the island's population, a blatant untruth, as the Emmanuels' and Klooster's numbers show. ${ }^{110}$ These statements clearly played on Dutch Protestants' pervasive fear of being overwhelmed by Catholics and Jews. These concerns are further seen in complaints that "no decent houses remained for Christians" and that the parnassim "have built a large, imposing church to make a name for themselves." 111 Jews were not to be trusted because, "according to the Talmud one may deceive another." 112 Moreover, contrary to objections (some made by the exact same complainants) that Jews monopolised trade and reduced the prices of merchandise, thereby ruining the island, the Jews were also poor and "there were too many needy Jews" and "the new Jewish arrivals were poor or of ill conduct." 113

That some settlers and WIC officials in Curaçao drew upon pervasive anti-Jewish stereotypes and rhetoric is not particularly unexpected. These sentiments express 
the same anxieties that the British colonists and colonial administrators voiced about incorporating Jews into their social order. On Curaçao, as Klooster says, "The cumulative effect of decades of connivance...was a wide variety of unwritten laws, which tended to deviate substantially from those upheld in the metropolis." 114 Thus, it is not surprising that there was low-level but persistent discrimination against Jews in Curaçao (and other Dutch Atlantic territories) and that this deviated from the official policy established in the metropolis, like the decree promulgated by the States General in July of 1657 according to which Jews and those of Jewish descent were equals as regards their rights abroad and foremost on the High Seas. As Dutch citizens, they enjoyed all the rights, privileges and immunities granted to nationals of the Netherlands, with the important exception of full political representation. ${ }^{115}$

\section{Contesting Citizenship in the Colonies}

The unswerving defence of Jews as Dutch citizens overseas (though not in the Republic itself) when confronted with foreign powers, particularly the Spanish, had a clear economic rationale. Even before the States General's general proclamation, the Dutch government had asserted in a diplomatic missive to the King of Spain that, "Portuguese Jews captured aboard a frigate called le Faulcon, travelling from Pernambuco in Brazil to Martinique were brought by adverse winds to Jamaica where they were put in prison. Their release is demanded by virtue of the fact that they are Netherlands nationals and residents" (my italics). ${ }^{116}$ This was followed by several other incidents involving Jewish merchants. For example, in July 23, 1657, the States General demanded the release of the goods and Portuguese Jews captured en route to the island of Barbados by Biscayan pirates and only a week later a similar request was given to the Spanish ambassador in The Hague regarding Jews in another incident. Thus, the States General clearly felt compelled to make a public declaration of the status of their Jewish overseas traders in order to protect their valuable cargoes and economic interests. ${ }^{117}$

But this pragmatic decision did not mean that the States General were prepared to accept that Jews could be full citizens, at least not if it was not in their economic interest to do so. Indeed, both the Dutch and the English were opportunistic in their interpretation of what citizenship meant vis-à-vis Jews, whether in their own country or another. In a telling controversy that erupted after Abraham Crijnssen conquered the settlement of Surinam for the Dutch in 1667, the Dutch stalled in allowing Jewish settlers to leave with the other English colonists as the terms of the peace treaty stipulated. One of the English negotiators wrote to the English government that "The Hollanders denied that the Jewes were his Majesties subjects or free denizens." 118 The Dutch argued that the Articles of Surrender mentioned only the "English" in the Dutch and English language translations and that, by their very nature, Jews could not be English. Interestingly, the English implicitly accepted this point and did not argue that the Jews were English. Instead, they turned to the original Latin document which said that all "subjects" of the English king were free to leave. ${ }^{119}$ The English negotiators also pointed out that, by the Dutch interpretation, the Scotch and Irish might not be able to leave either because they were not English. 
Negotiations were drawn out over seven years on behalf of ten Portuguese Jewish planters with 322 slaves who desired to immigrate to Jamaica from Surinam under the terms of the Treaty of Breda, and, eventually, the Jews were allowed to leave. At the same time, the government that denied the privileges of English subject to Jews, even those long resident or born on English soil, was quick enough to insist that Jews resident in Surinam were English subjects because it was economically advantageous to do so. ${ }^{120}$ Likewise, the Dutch, who were more than willing to assert that Jews were Dutch nationals and residents when they and their valuable cargoes were captured by the Spanish, would quibble over whether or not Jews could be or were English when they hoped to retain these valuable settlers for their own recently-won colony, though they still did not give Jews full citizenship rights in the Republic itself. ${ }^{121}$

The unease occasioned by the uncertain citizenship status most often played out in the economic sphere, usually via the courts, as the boundaries between law and popular perception were negotiated in the colonial Atlantic world. For instance, though the English insisted that the Jews in Surinam were English subjects, various colonial officials were less sure. In a well-known case from the seventeenth century, Royal Customs agent Samuel Hayne claimed that the thirty-five Jewish traders who had goods on the ship Experiment were guilty of trying the cheat the Crown out of $£ 154$ in alien duties due under the Navigation Acts. ${ }^{122}$ His claim was based on the fact that the Jewish traders had entered the cargo under the name of the captain, an English Quaker, because they were unable to trade as English subjects. When Antonio Gomesserra and Antonio Baruch Lousada, two endenized Jewish merchant partners, came forward and claimed the cargo, a jury ruled in their favour. Haynes was outraged and later wrote a pamphlet claiming that Jews, whether endenized or not, would always constitute a separate and unequal class of subjects. ${ }^{123}$ All this shows that English law, as promulgated in the metropolis, upheld a definition of citizenship that included Jews despite the very real and pervasive popular repugnance at, and unease with, the idea that Jews could be Englishmen.

The equally well-known case of the Jewish merchant Rabba Couty emphasises this popular repugnance. ${ }^{124}$ In 1671 Couty's ship, The Tryall, was seized upon arrival in Jamaica because it was not an English ship. Couty appeared before the Admiralty Court and presented a license from the governor of New York stating that he was an English denizen. However, the court ruled that "hee [Couty] was no Denizen" and that "Rabba Couty being not an Englishman, but a Jew was for this cause to be accompted a Forreigner" and should promptly be condemned to lose his boat and its cargo as a prize, which is precisely what happened. ${ }^{125}$ The Couty case underscores the fact that no matter what the law said, in the English Atlantic world popular opinion held that Jews were outsiders and not legitimate citizens.

These sorts of cases were not limited to the British Atlantic, however. In the last quarter of the eighteenth century, Jews were refused passports to go to the Dutch colonies of Essequibo and Demerara, which was in stark contrast to the encouragement Jews had continually received to settle in neighbouring Suriname. ${ }^{126}$ The WIC officials asserted that prospective Jewish settlers were undesirable, and even dangerous, as colonists and alleged that Jews in Suriname were known to buy goods stolen by slaves from their masters, and thereby encouraged the slaves' bad behaviour. David Nassy wrote that the "magistrates of Essequibo and Demerary, subjects 
of the Republic of Holland, have again fabricated invectives against the Jews." ${ }^{127}$ Nassy believed that these accusations came from "fear of having them [the Jews] as competitors in their unfortunate colonies." ${ }^{128}$ Whatever the reasons behind this refusal to allow Jews into these colonies, the fact that they could be singled out as a group and refused admission to a Dutch Atlantic settlement shows that how the status of Jews was negotiated depended on local arrangements, including the power of the governors and ruling councils of the various settlements.

In this respect, not much had changed in the century since Peter Stuyvesant, governor of New Amsterdam, tried to stem the influx of Jews from Dutch Brazil into his colony. Stuyvesant said that "To give liberty to the Jews will be very detrimental." He warned that they would take business from Christians. Moreover, allowing the Jews in New Amsterdam would set a bad precedent. Once Jews were permitted, "we cannot refuse the Lutherans and Papists." ${ }^{129}$ As James Home Williams points out, even as Jews with a Dutch identity were being asked to leave New Amsterdam, English refugees from New England were forming towns a few miles away on western Long Island. Although the Dutch rightly questioned their loyalty, Stuyvesant assumed the best from the English because they were "brothers" in the Calvinist religion-a brotherhood in which Jews could never share. ${ }^{130}$

Ordered by the WIC to allow Jews in the colony, Stuyvesant and his council did their level best to deny them the rights and privileges of Dutch citizenship. In April 1657, Asser Levy petitioned for burgher rights, the first Jew to do so. He argued that the same privileges had already been granted to Jews in the Netherlands and he presented a copy of his poortersbrief from the City of Amsterdam to help make his case. The rights and privileges granted to Jews in Amsterdam served as the model for rights and privileges in the colonies. ${ }^{131}$ However, this logic initially failed to prove persuasive in New Amsterdam. ${ }^{132}$

Acquisition of citizenship or the burgher right was of great importance to the Jewish settlers not just because of the legitimation of belonging it brought, but also because of the economic entrée it gave them. For instance, a regulation adopted in New Amsterdam around 1654 held that "henceforward, traders arriving cannot trade without setting up and keeping an open store in a hired or owned house or rooms, and to ask the common or small burgher right (paying 20 guilders therefor) and have subjected themselves by subjection or promise of oath to bear their burden, expenses, expeditions and watches like other burghers and citizens". ${ }^{133}$ As a result, failure to attain the status of citizen would likely also mean financial failure.

As is clear from the various examples of discriminatory actions in the British and Dutch Atlantic - extra or excessive taxation, general defamatory remarks and threats, and attempts to limit the economic possibilities of Jews, not to mention limited access to political participation and representation -non-Jewish settlers and colonial administrators were frequently unwilling to fully accept Jews into their respective folds. They often restricted Jews' economic opportunities by contesting their status as citizens deserving of the rights and privileges implied by belonging to a given polity. Yet these attempts to curb the economic and political rights of Jews came from the settlers and colonial officials in the colonies themselves. The governments in Britain and the Dutch Republic almost unwaveringly supported their Jewish settlers, as we shall see in the following section. All of which illustrates the difficulty in navigating between the economic imperatives of empires dictated by the 
metropole which had to be carried out by locally-based colonial administrators. Living side-by-side with Jews, competing (and sometimes cooperating) with them meant that those in the colonies were confronted with deeply ingrained ideas of what it meant to belong-or not-to an economically and socially constructed community.

\section{Assertion of Belonging: Obligations, Rights, and Allegiance}

The Jews, for their part, were generally able to play off competing colonial interests against each other. Thanks to an intimate knowledge of their privileges under various systems of law, they were skilful in employing legal and rhetorical arguments to assert their rights in the colonies. Their arguments not only focused on the finer points of law but also employed a rhetoric of loyalty and belonging. Proving loyalty and asserting belonging often meant demanding the right to fulfil duties such as serving in the civil militias, in order to emphasise the reciprocity of obligations between the state and its citizens.

In the case mentioned above, the Jewish communities of Amsterdam and Surinam actively protested the decision not to grant passports to Jews to settle in Essequibo and Demerara-a controversy that occurred between 1774 and 1776. They wrote directly to the Provincial States of Holland and then to the States General itself addressing the issue of the refusal to allow Jewish settlement in these territories. They addressed the claim that Jews were known to engage in illicit acts, including buying stolen goods from slaves, but they did not directly refute it. Instead, in a series of appeals, the Jewish community asserted their rights to settle on the basis of legal precedents, they appealed to the Dutch Republic's economic interests, and they argued that theirs was a case of simple fairness.

The parnassim wrote the States General that, "The Nation [the Jews] have been admitted to all the colonies and islands which belong to this Republic....and have been recognized by the High and Mighty States of Holland as subjects and residents of this Republic, and...are therefore respectfully confident that they shall be allowed to enjoy the same rights which are enjoyed by the other residents of this State."134 Though they go on to "humbly request" that their case be considered, the parnassim then rather assertively declare, "those of Portuguese Jewish Nation are entitled [emphasis mine], like the other residents of this State, to continue to settle in Essequibo and Demerara, as well as in the other Colonies and islands of this State." ${ }^{135}$ Thus, they stress that they hold the same rights as any other residents, despite the fact that they are Jewish. In fact, they are, they argue, entitled to these rights.

In a separate document to the assembly of the province of Holland, the Jewish community declared that the reasons for their request to settle in Essequibo and Demerara "shall be found to be entirely legal and sufficient, the more so since the Suppliants are so fortunate to be able to appeal to a resolution of Your High and Mightinesses of the 12th of July 1657 by which those of the Jewish Nation in this country were declared...subjects...and residents of these same United Netherlands and as such entitled to enjoy the conditions, rights and advantages...for the residents of this State." ${ }^{136}$ This passage shows that the Jewish community knew their rights, were aware of legal precedents, and would not hesitate to point out the ille- 
gality of refusing them the right of settlement. To emphasise this point, they even included a copy of the decree issued by the States General in 1657 upon which they based their arguments in support of their claims.

Beyond their entitlements as subjects_rights equal to those of other residentsto settle in the colonies, and the legal precedents ensuring these rights, the parnassim also adroitly focused on fairness. Taking on the excuse proffered by the directors of Essequibo and Demerara - that Jews engaged in illicit activities and were, therefore, undesirable colonists - the leaders of the Jewish community asserted that "even if it is true that among those of the Nation...there have been such who were so perfidious as to commit such unacceptable and punishable collusive acts... this should not rebound to the repute of the entire Nation, but that the criminals among them alone ought to be punished in an exemplary manner...It would be extremely harsh if those of the Jewish Nation who have already settled in Essequibo and Demerara, or are intending to settle there, should have to suffer because of the misdeed and perfidy of one or more of their Nation....and should be blamed for such matters." 137 In making this argument, they assumed that the authorities would be swayed by appeals to reason and justice.

But in case the governors were not be convinced by legal precedents and calls for fairness, the parnassim made sure to underscore the economic importance of the Jews to the colonies. They wrote the States General that:

The Suppliants...have, through their diligence and industry, as well as by bringing their treasures and property to this country, considerably contributed to continuing and maintaining the trade which is so highly needed by this Republic... [and that] it is now more than ever desirable, that everything possible be done to support and maintain trade and commerce in this country, to which end the exclusion of the Portuguese Jewish Nation from the said Colonies of Essequibo and Demerara, with respect, does not seem to be the right means, certainly not in this time in which even intolerant Princes, in order to support trade and commerce in their countries, have not only granted several rights to those of the Jewish Nation, and given them the same rights as their other subjects, but even have granted them privileges and immunities. ${ }^{138}$

This passage, quoted at length because of its importance, illustrates that the Jewish community was well-aware of their past value to the Dutch colonies. Moreover, they not-so-subtly highlighted that the current economic situation was less than optimal so that "now more than ever" it was desirable to do anything possible to "support and maintain trade and commerce" by allowing Jewish settlement. The parnassim also deftly demonstrated a keen understanding of imperial rivalries by implying that they could take their trade elsewhere because "even intolerant Princes" had granted Jews rights and privileges comparable to those of their other subjects.

The States General agreed with the Jewish community's arguments. In a rather brief response, they recognised the legal precedence for Jewish settlement in Essequibo and Demerara and made reference to the resolution of 1657 upon which this right was based. They ordered that passports be granted to Jews wanting to travel to these colonies without delay. What is striking about this case was the confidence with which the Jewish community asserted its rights. Their petitions show 
a sure and certain knowledge of the legal justification for their settlement. Throughout the documents, they "demand" their rights and emphasised their "entitlement" to go where they wish within the Dutch Atlantic world. They are "respectfully confident" that their rights will be acknowledged and respected. Thus, their rhetoric is focused on legality and the fairness to which they are entitled as equal citizens.

For instance, when Rabba Couty's ship was seized, he first showed his license from an English colonial administrator, Colonel Francis Lovelace, who was the British governor of New York. When the Admiralty Court in Jamaica ruled against him, Couty sailed to New York in order to get yet another certificate from Lovelace that confirmed that he was "a Free Burgher of this Citty" and that his ship and crew were English. This was necessary for Couty to appeal the seizure of his ship to the king. The Privy Council was then given the task of investigating the case. They found that "the said sentence [in Jamaica] to be grounded on a presumption that the said Rabba Couty [was] not an Englishman." They further ruled that this was in opposition to colonial practice and that the certificates were sufficient to establish that Couty was "an Inhabitant and free Cittyzen of your Majestyes Plantations." Couty, then, used the legal structures in place regulating the English colonies to assert his rights and, ultimately, his belonging as a citizen in the English Atlantic.

Likewise, when Customs Inspector Hayne seized the ship Experiment, Antonio Gomesserra and Antonio Baruch Lousada, employed the legal structures available within the English (colonial) system. They took the case to an English jury. The merchants showed their patents of endenization from the Crown (issued in 1672 and 1675, respectively) in order to assert the fact that they were not officially aliens and, therefore, were not obliged to pay alien duties on the cargo that Hayne had seized. ${ }^{158}$ Despite the fact that Hayne argued that an Alien customs fee should be charged to all Jewish merchants because a Jew could never be an Englishman, the legal system to which Lousada and Gomesserra appealed ruled in their favour.

The Jews had also employed rhetoric underscoring legality, justice, and economic utility when, about 125 years before, they appealed Peter Stuyvesant's discriminatory actions in New Netherland. But in contrast to the appeals made at the end of the eighteenth century, the Jewish community in the mid-seventeenth century also used arguments which underscored their loyalty and belonging. Perhaps this difference in the language employed by the parnassim in the latter part of the eighteenth century hints that there had been a progression in terms of their confidence in their legal position in the Republic and its overseas possessions. Be that as it may, they felt compelled to emphasise loyalty and assert belonging in the seventeenth century. To prove this loyalty and to assert this belonging, they demanded to fulfil duties associated with citizenship, such as serving in the civil militias. This was the case not just in New Netherland, but also in Curaçao and other Dutch Atlantic colonies.

When Stuyvesant tried to expel Jewish refugees from Dutch Brazil from New Amsterdam, the Jewish community in Amsterdam sprang into action on behalf of their co-religionists. They petitioned the Amsterdam chamber of the WIC and reminded the directors that not all the refuges could be accommodated in Amsterdam and that preventing Jewish immigration to New Amsterdam would "hinder the Company" economically. The country around New Netherland was 
"extensive and spacious" and there was a great deal of income to be derived from Jews living there. ${ }^{139}$ These were all the standard arguments in favour of Jewish colonial settlement based on economic utility. But the parnassim also used the language of loyalty and fairness. It would be "unfair" to those Jews who had "at all times been faithful" and who had risked their "possessions and their blood" for the Company in Brazil. After all, the parnassim wrote, "the more of loyal people that go to live [in the colonies] the better it would be." Thus, they cleverly asserted not only the economic utility of the Jews, but also the Jews as loyal citizens-loyal citizens to whom the WIC had an obligation because of their losses in Brazil.

The WIC agreed with the Amsterdam Jewish community on all the grounds upon which they had argued. They wrote Stuyvesant that the Jews should be allowed to settle in New Netherland because "of the large amount of capital they still have invested in shares of the company." The Jews had suffered considerable losses in Brazil. Therefore, the WIC directors concluded, it would be "somewhat unreasonable and unfair" to send them away from New Netherland. Economic usefulness and fairness, combined, had swayed the directors of the WIC in favour of the Jews. But the arguments were not enough to convince Stuyvesant and his council to welcome Jewish settlement.

Asser Levy's attempts to assert his rights in New Netherland, briefly mentioned above, are a case in point. ${ }^{140}$ In 1655 , Levy demanded to be allowed to fulfil the obligations of citizenship within the colony by serving in the civil guard. In a resolution passed that same year, Stuyvesant and his council exempted Jews from military service in the civil guard and imposed a special tax on them in lieu of serving. This exclusion was justified because the captains and other members of the militia felt "aversion and disaffection...to be fellow soldiers...and to mount guard in the same guardhouse" with Jews. ${ }^{141}$ Moreover, they pointed out that Jews in Amsterdam or other Dutch cities did not serve in the civil militias, and, instead, paid a fee in exchange for service. However, Levy (and fellow Jew Jacob Barsimson) argued that they could not afford the exemption fee. ${ }^{142}$

Indeed, it is likely that as manual labourers Levy and Barsimson would have had trouble paying the exemption fee. But it is also the case that serving in the militia, as other male settlers did, was part and parcel of belonging to the larger community. In the Dutch Republic civic militias were of great importance, especially as a means of political mobilisation for the middle classes. ${ }^{143}$ Serving in the civil militias, particularly in the colonies, similarly demonstrated the fulfilment of obligations to the larger community by a (male) citizen, and, in turn, there was understood to be a reciprocal obligation on the part of this community to the citizen who served. Levy was eventually allowed to serve.

Thus, when Asser Levy was initially denied a certificate of citizenship in New Amsterdam in 1657, he claimed that "burgherschap [in New Netherland] ought not be refused him as he keeps watch and ward like other Burghers." ${ }^{144}$ With this statement, he asserted quite clearly that he had fulfilled his obligations to the community and, therefore, should not be refused the rights inherent in holding citizenship. The council's initial refusal of citizenship rights was detrimental to Levy on several fronts. Burghers of New Amsterdam were clearly distinguished from non-burgers who were unable or unwilling to make the same commitment to belonging to this new urban community. ${ }^{145}$ This belonging played itself out symbolically and practi- 
cally. If Levy was not a citizen of New Amsterdam, his rights to trade would be severely limited.

Not to be denied, Levy appealed and asserted his rights to citizenship based on legal arguments, in addition to his claim of having served in the militia, showing that he was fulfilling the obligations of a (male) citizen. He showed his certificate (poortersbrief) of citizenship from the city of Amsterdam to legitimate his claim. The representatives of the Jewish community petitioned the directors of the WIC on his behalf (and on behalf of the other Jews in the colony). They wrote that "We should enjoy all the same privileges as other inhabitants of New Netherland... [and] that our nation enjoys in the City of Amsterdam in Holland...We reverently solicit that you will not now exclude us from the rank of citizens, but rather to incline the Hon. Burgomasters that they will permit us to enjoy with other citizens their privileges, and grant to each person who might solicit that favour, a certificate of their citizenship." 146 The parnassim went on to emphasise that "Our nation, as long as we resided here [Amsterdam] did bear her share with others in every burden of the citizens." ${ }^{477}$ For the representatives of the Jewish community in Amsterdam, Levy was a burgher in Amsterdam and, therefore, was entitled to be a burgher in New Amsterdam. Thus, for Levy and his fellow Jews, his rights and responsibilities should be equal in the colonies and in the metropole. Moreover, they highlighted that their community had shared the responsibilities ("burdens") of other citizens. They were, therefore, responsible, loyal, and worthy of the privileges of citizenship in New Netherland.

The claim that one was a responsible community member who, in turn, expected certain privileges for supporting the government was exercised by many settlers in Dutch-controlled territories when they first ventured into the Atlantic world. ${ }^{148}$ As Wim Klooster notes, "In other New World holdings of the WIC like Curaçao, participation in the burgher guard was an obligation of a citizen." ${ }^{149}$ On Curaçao, each man-Dutch-born or not-who took up his abode on the island, was registered with the civic guard after a stay of one year and six weeks. In fact, as Klooster points out, citizenship, as a concept, lost its rationale on Curaçao beyond the military obligation of serving in the civil guard. ${ }^{150}$ Thus, excluding Jewish men from serving in the civil militias, in a matter of speaking, excluded them from citizenship, a point implicitly recognised by the Prussian correspondent of the Surinamese Jewish community, C.W. von Dohm, when he inquired of them, "Have you the right to defend the common fatherland as soldiers, and to serve it as civil or military officers?"151

Excluding Jews from this right is just what fiscaal Petersen tried to do in 1737 and 1738 on Curaçao. Petersen submitted a report to the WIC directors saying that Jews should be excused from serving in the militia because they "were not adept at the use of arms" but should, instead, pay a tax in lieu of service. ${ }^{152}$ This despite the fact that Jews had been noted by various observers as having been quite active in the military defence of the island, especially during the famous attack of the French pirate Jacques Cassard in 1713. ${ }^{153}$ Peterson's attitude toward Jews serving in the military was hardly unique, and Jews were excluded from serving in the military and civil militias in most European lands until the nineteenth century. ${ }^{154}$ This was certainly not the first time that service in the civil guard on Curaçao had served as the flashpoint for issues concerning the rights and privileges of Jews. When a conflict arose in 1701 about whether Jews should allow their slaves to work on Saturdays, 
the Jews refused, but they emphasised how, in times of peril, the Jews (and their slaves) had done voluntary guard duty on Saturdays and would again, should it be necessary. Although Jews were exempted from serving in the militia on Saturdays, the parnassim emphasised that Jews had served on Saturdays when the French attacked the island in 1673 and 1678, and during a pirate attack in $1684 .{ }^{155}$ Likewise, Moses Naar of the citizens' company of the Portuguese Jewish community in Suriname was awarded a silver coffee service valued at 150 Dutch guilders for "showing zeal, vigilance, and good service" in an expedition against escaped negroes, including service on Saturday in 1740. ${ }^{156}$ The Jewish community in the Dutch Atlantic, therefore, underscored their willingness to fulfil the obligations of all citizens, even if, according to their privileges, they did not have to.

The same issues about Jewish service in the civil militias popped up in the British Atlantic, as well. In the mid-eighteenth century Jews on Jamaica were required to serve in the civil guard, just like all other male citizens on the island, but they hoped to be excused from service during their Sabbath and holidays, as they were on Curaçao. When they appealed to the parnassim in London to lobby for their exclusion, they were strongly urged not to ask for special privileges. Instead, the parnas$\operatorname{sim}$ in London gave them a dispensation if they served on the Sabbath or on Jewish holidays, especially if martial law was in force. ${ }^{157}$ This was a clear attempt on the part of the leaders of the Jewish community in London to make sure that their brethren in the Atlantic colonies were, first and foremost, perceived as trustworthy and loyal settlers who fulfilled their obligations and not first and foremost as Jews.

All of these cases show that Jews were generally quite successful in appealing to the legal structures available for the assertion of their citizenship rights in both the Dutch and British Atlantic contexts. The Jews in the Atlantic, in time-honoured tradition, continually appealed to their "home" communities in Amsterdam and London. These communities, in turn, were skilful in employing legal and rhetorical arguments designed to influence the ultimate decision makers in the metropole for the assertion of their brethren's rights in the colonies. ${ }^{159}$ The Jewish communities' claims to the rights and privileges inherent as citizens involved an intimate knowledge of the systems of law. But the assertion of these claims to citizenship meant employing not just a rhetoric of legality, but also a discourse of loyalty and belonging intended to emphasise the reciprocity of obligations between the state and its citizens.

\section{Conclusion}

The particular issue of the Jews in the British and Atlantic colonies in the seventeenth and eighteenth centuries fits into current discussions about the emergence of nations and ideas of what it meant to belong to these nations as citizens. Until relatively recently, there were two opposing tendencies in the study of nations and citizenship. On the one side were studies asserting that nations already existed during the early modern period (or even earlier). ${ }^{160}$ On the other side, some scholars posited the inherent modernity of nations. ${ }^{161}$ Despite their seeming opposition, however, both outlooks view the nation as either a "natural" and inevitable phenomenon, or an historical product that was ideologically or politically constructed. ${ }^{162}$

Tamar Herzog, in contrast, calls into question many of these assumptions 
employed in current debates on the emergence of nations in early modern Europe based on her studies of Spain and Spanish America. She writes that "communities are neither naturally given nor fictitiously imagined...communities are continuously shaped by a multiplicity of agents acting under a variety of circumstances and motives. They are created and modified through both agreement and conflict, and they reflect the working of different and often contesting models of communal construction and membership." ${ }^{63}$ In Herzog's view, then, individuals and institutions were constantly engaged in fighting to preserve their privileges and, in the process, also in defining what it meant to be part of a community.

As this article has shown, the case of the Jewish communities in the British and Dutch Atlantics in the seventeenth and eighteenth centuries supports Herzog's contentions. Jews constantly (re)negotiated contesting of models of communal construction and membership. They also needed to persistently assert their rights and privileges to belong to these communities. This is not surprising because the imperial project itself necessitated some sort of change in the perception of who belonged and who did not. Therefore, the categories of "foreigner" and "foreignness" carried a more ambivalent message.

The pragmatic imperatives of settlement and the development of colonial economies which argued for incorporating "foreigners" such as Jews into the imperial project also served to exacerbate the already existing tensions surrounding the inclusion of culturally, religiously, and/or ethnically distinct groups within the larger community, often with new complications particular to colonial settings. ${ }^{164}$ Moreover, it brought to the fore the need to create a legal and, ultimately, a cultural framework in which culturally distinctive groups such as Jews could manoeuvre. The legal frameworks within which they operated established institutional routines for recognising their "otherness" and for providing them legal recognition and protection. ${ }^{165}$ In practical terms, this meant the extension of citizenship, even if in a limited form: for instance, in the absence of the right to political representation, to Jews in the colonies.

The ways in which the extension of citizenship to Jews was perceived, contested, and asserted demonstrate the changing notions of cultural boundaries because citizenship itself implied a sharing of identities. There was an underlying assumption that Jews did not share the attributes of the rest of British or Dutch society and never could. Not even the most ardent supporters of Jewish colonisation argued for the innate "Britishness" or "Dutchness" of Jews. Ideas of belonging such as that expressed by polemicist William Romaine who wrote that, "our state can have no natural-born Subjects but Christian, and a natural-born Jew Christian Foreign Englishman, is such a Medly of Contradictions, that all the Rabbies [sic] in the World will never be able to reconcile them" were echoed, though admittedly to a lesser extent, in the Dutch Atlantic. ${ }^{166}$ For instance, planters in Suriname (unsuccessfully) argued to exclude Jews from elections of members of the Council of Policy as "no other Christian nations permit or suffer Jews to take a hand in running the affairs of the country." 167

Despite these doubts about the incorporation of Jews into the (colonial) community, the Jewish community itself asserted their rights to belong, economically and socially, by employing the legal structures already in place for the protection of their privileges. But they also used the language of loyalty and service in order to empha- 
size the reciprocity of obligations. As part of this on-going process, Jews scrambled ideas of "national" allegiances and were active agents in the negotiation of citizenship rights across imperial boundaries. In a sense, the case of the Jews in the British and Dutch colonial orbits are a precursor to larger debates about national belonging and exclusion that that emerged in the nineteenth century with the idea of the nation-state.

\section{Bibliography of Works Cited}

\section{Primary Sources}

Nationaal Archief, Den Haag (NL-HaNa) [Dutch National Archive, The Hague]

Tweede West-Indische Compagnie (WIC) [Second West India Company] 1.05.01.02

70, 8v-99; 201, 385v; 205, 36v, 80v-81v, 125, 501; 206,149v; 210, 55-76; 336, 11v, 190v, 343v, 383 v; 357, 15; 521v-22; 579, 39; 585, 608v-28

Staten-Generaal [States General] 1.01 .02

129, 29; 142, 225; 146, 322

Amsterdam Municipal Archive (SAA)

Portugees-Israëlietische Gemeente [Portuguese Jewish Community] 334

94, 20-21, 73; 118-119, 360-361

\section{Published Primary Sources and Inventories of Primary Sources}

Acts of Assembly, passed in the island of Jamaica; from 1681 to 1737, inclusive. London: Baskett $\mathcal{E}$ Baskett, 1743.

Archaicus [pseud.]. Admonitions from Scripture and History: from religion and common prudence, relating to the Jews. London: printed for R. Baldwin, jun.; and S. Parker in Oxford, 1753.

Barnett, Lionel D., ed. Bevis Marks Records: Contributions to the History of the Spanish and Portuguese Congregation of London. 5 vols. Oxford: Board of Elders of the Congregation, 1940-1993. Vol. 1.

O'Callaghan, Edmund B., ed. Laws and Ordinances of New Netherland, 1638-1674. Albany: Weed, Parsons, 1868.

The Case of the Jews Stated. [London?], November 11, 1689. Reprinted Transactions of the Jewish Historical Society of England 9 (1922): 44-6.

Cobbett, William. Parliamentary History of England from the earliest period to the year 1803: from which last-mentioned epoch it is continued downwards in the work entitled "The parliamentary debates," Vols. 1-36. London: Hansard, 1806-1820. Vol. 14.

Corte ende waerachtighe beschrijuinge van eenen jode, ghenaemt: Asvervs of Wandelende jood. Leiden: 1603. Koninklijke Bibliotheek [Dutch National Library], Pamphlet Nr. 01242b.

Court, Pieter de la. Interest van Holland oft Gronden van Hollands Welvaren. Amsterdam, 1662.

Extract uyt de resolutien van de Heeren Staaten van Holland en Westuriesland, in haar Edele Groot Mog. vergadering, 1770. [The Hague?], [1770?].

Fernow, Berthold, ed. The Records of New Amsterdam from 1653 to 1674 Anno Domini: Minutes of the court of burgomasters and schepens, 1656 to Aug. 27, 1658, inclusive, 7 vols. New York: Knickerbocker Press, 1897. Vol. 2.

Hartsinck, J.J. Beschrijuing van Guyana of de Wilde Kust in Zuid Amerika. Amsterdam, 1770. Vol. 2.

Hayne, Samuel. An Abstract of All the Statutes Made Concerning Aliens Trading in England...Proving that the Jews...Break Them All. London, 1685.

Headlam, Cecil, and Arthur Percival Newton, eds. "America and West Indies: April 1733, 16-30," Calendar of State Papers Colonial, America and West Indies, Volume 40: 1733, British History Online, http://www.british-history.ac.uk/report.aspx?compid=79269.

De hoogduitsche Jood, met zyn politieke rarekiek-kas, die hy van zyn vader geerft heft, N.p.: 1675. Bibliotheek der Rijksuniversiteit Groningen [University of Groningen Library], Pamphlet Nr. 01675. 
Long, Edward John. The History of Jamaica, or General Survey of the Ancient and Modern State of that Island: with Reflections on Its Situations, Settlements, Inhabitants, Climate, Products, Commerce, Laws and Government. 3 vols. London: Lowndes, 1774. Vol. 2.

Mission, Francois-Maximilian. A New Voyage to Italy, 2 vols. London, 1714.

Nassy, David. Historical Essay on the Colony of Surinam 1788, edited by Jacob R. Marcus and Stanley F. Chyet. Cincinnati/New York: KTAV Publ. House, 1974.

d'Oliveira França, Eduardo, and Sonia Siquiera, eds. "Segunda visitação do Santo Ofício ás partes do Brasil: Livro das confissões e ratificações da Bahia, 1618-1620.” Anais do Museu Paulista 17 (1963): 121-547.

Resolutien van de Heeren Ridderschap, Edelen ende Gedeputeerden van de Steden van Hollandt ende West Vrieslandt, January 1619. N.p., n.d.

Romaine, William. An Answer to a Pamphlet, Entitled. "Considerations on the Bill to Permit Persons Professing the Jewish Religion to be Naturalized." London, 1753.

Sainsbury, W. Noel, ed. "America and West Indies: December 1670." Calendar of State Papers Colonial, America and West Indies. Vol. 7: 1669-1674, no. 367. British History Online, http://www.britishhistory.ac.uk/report.aspx?compid=70202 .

_. "America and West Indies: July 1672." Calendar of State Papers Colonial, America and West Indies. Vol. 7: 1669-1674, no. 879. British History Online, http://www.british-history.ac.uk/ report. aspx?compid $=70225$.

. "America and West Indies: List of Colonial Entry Books." Calendar of State Papers Colonial, America and West Indies. Vol. 7: 1669-1674. British History Online, http://www.british-history. ac.uk/ report. aspx?compid $=70280$.

- "America and West Indies: September 1670, 16-30," Calendar of State Papers Colonial, America and West Indies. Vol. 7: 1669-1674, no. 264. British History Online, http://www.britishhistory.ac.uk/ report.aspx?compid $=70199$.

- "America and West Indies: November 1672." Calendar of State Papers Colonial, America and West Indies. Vol. 7: 1669-1674. British History Online, http://www.british-history.ac.uk/ report.aspx?compid $=70229$.

—. "America and West Indies: December 1672." Calendar of State Papers Colonial, America and West Indies. Vol. 7: 1669-1674. British History Online, http://www.british-history.ac.uk/report. aspx?compid $=70230$.

Verslag der Handelingen van de Tweede Kamer der Staten-Generaal, meeting of 6 December 1873.

Webb, Philip Carteret. The Question whether a Jew born within the British Dominions could before the late Act purchase and hold Lands. By a Gentleman of Lincoln's Inn. London, 1753.

\section{Secondary Sources}

Alberro, Solange. "Crypto-Jews and the Mexican Holy Office in the Seventeenth Century." In The Jews and the Expansion of Europe to the West, 1450-1800, edited by Paolo Bernardini and Norman Fiering, 172-85. New York: Berghahn, 2001.

Anderson, Benedict. Imagined Communities. London: Verso, 1991.

Arbell, Mordechai. The Jewish Nation of the Caribbean: The Spanish-Portuguese Jewish Settlement in the Caribbean and the Guianas. Jerusalem: Gefen, 2002.

- "Jewish Settlements in the French Colonies in the Caribbean (Martinique, Guadeloupe, Haiti, Cayenne) and the 'Black Code'". In The Jews and the Expansion of Europe to the West, 1450-1800, edited by Paolo Bernardini and Norman Fiering, 287-313. New York: Berghahn, 2001.

Baião, António. A Inquisição em Portugal e no Brazil. Subsídios para a sua História. Lisbon: Arquivo Histórico Português, 1906.

Baron, Salo Wittmayer. A Social and Religious History of the Jews. 18 vols. 2nd ed. New York: Columbia University Press, 1952-83. Vol. 15.

Bell, Dean Phillip. Jews in the Early Modern World. New York: Rowan, 2008.

Benton, Lauren. Legal Regimes and Colonial Cultures. Cambridge: Cambridge University Press, 2002.

Berg, Peter A.J. van den. "Inboorlingschap en Ingezetenschap in de Republiek der Verenigde Nederlanden, 1600-1795." Tijdschrift voor Rechtsgeschiedenis/Legal History Review 71 (2003): 125-53.

Berkovitz, Jay R. The Shaping of Jewish Identity in Nineteenth-century France. Detroit: Wayne State University Press, 1989. 
Böhm, Günter. "Crypto-Jews and New Christians in Colonial Peru and Chile." In The Jews and the Expansion of Europe to the West, 1450-1800, edited by Paolo Bernardini and Norman Fiering, 203-12. New York: Berghahn, 2001.

Brackman, Harold D. "The Ebb and Flow of Conflict: A History of Black Jewish Relations through 1900." Ph.D. diss., University of California, Los Angeles, 1977.

Burnard, Trevor. "Who Bought Slaves in Early America? Purchasers of Slaves from the Royal African Company in Jamaica, 1674-1708." Slavery and Abolition 17:2 (1996): 68-92.

Cohen, Robert. Jews in Another Environment: Surinam in the Second Half of the Eighteenth Century. Leiden: Brill, 1991.

Davis, David Brion. "The Slave Trade and the Jews." New York Review of Books, December 22, 1994, 14-16.

Davis, N. Darnell. "Notes on the History of the Jews in Barbados." Publications of the American Jewish Historical Society 18 (1909): 129-48.

Diner, Hasia R. In the Almost Promised Land: American Jews and Blacks, 1915-1935. Westport: Johns Hopkins University Press, 1977.

Drescher, Seymour. "Jews and New Christians in the Atlantic Slave Trade." In Jews and the Expansion of Europe, edited by Paolo Bernardini and Norman Fiering, 439-70. New York: Berghahn, 2001.

. "The Role of Jews in the Transatlantic Slave Trade." Immigrants and Minorities 12 (1993): 113-25.

Dubin, Lois. "Introduction: Port Jews in the Atlantic World." Jewish History 20:2 (2006): 117-27.

Dym, Jordana. "Policing Nueva Guatemala: The Alcaldes de Barrio Controversy, 1761-1821." Unpublished paper presented at the Eighth International Conference on Urban History, Stockholm 20 August-2 September 2006.

Emmanuel, Isaac S., and Suzanne A. Emmanuel. History of the Jews of the Netherlands Antilles. 2 vols. Cincinnati: American Jewish Archives, 1970.

Endelman, Todd. The Jews of Georgian England, 1714-1830. Ann Arbor: University of Michigan Press, 1979.

Faber, Eli. Jews, Slaves and the Slave Trade: Setting the Record Straight. New York: New York University Press, 1998.

Felsenstein, Frank. Anti-Semitic Stereotypes: A Paradigm of Otherness in English Popular Culture, 1660-1830. Baltimore: John Hopkins University Press, 1995.

Fortune, Stephen Alexander. Merchants and Jews: The Struggle for British West Indian Commerce, 1650-1750. Gainesville: University of Florida Press, 1984.

Frank, A., and H. Brugmans. Geschiedenis der Joden in Nederland. Amsterdam: Van Holkema, 1940.

Friedenwald, Herbert. "Material for the History of the Jews in the British West Indies." Publications of the American Jewish Historical Society 5 (1897): 45-101.

Fuks-Mansfeld, R.G. De Sefardim van Amsterdam tot 1795. Aspecten van een joodse minderheid in een Hollandse stad. Hilversum: Hollandse Historische Reeks, 1989.

Gaaij Fortman, A. de."Een Belangrijk Dagboek: Journael wegens de comste en onderneminge der france vloot onder 't commando van Mons. Cassard voorgevallen op Curaçao. 1713." De Nieuwe WestIndische Gids 6:1 (1924): 241-70.

Gilman, Sander. The Visibility of the Jew in the Diaspora: Body Imagery in Its Cultural Context. Syracuse: Syracuse University Press, 1992.

Godfrey, Sheldon J., and Judith C. Godfrey. Search Out the Land: The Jews and the Growth of Equality in British Colonial America, 1740-1867. Montreal: McGill-Queens Press, 1995.

Goldish, Matt, ed. Jewish Messianism in the Early Modern World. Dordrecht: Kluwer, 2001.

Gonsalves de Mello, José Antônio. Gente da Nação: Cristãos-novos e judeus em Pernambuco, 1542-1654. Recife: Editora Massangana, 1996.

Gould, Eliga H. "To Strengthen the King's Hands: Dynastic Legitimacy, Militia Reform and Ideas of National Unity in England, 1745-1760." The Historical Journal 34:2 (1991): 329-348.

Hastings, Adrian. The Construction of Nationhood. Ethnicity, Religion and Nationalism. Cambridge: Cambridge University Press, 1997.

Henriques, H.S.Q. The Jews and English Law. Clifton: Augustus M Kelley, 1908.

Hershkowitz, Leo. "Dutch Notarial Records Pertaining to Asser Levy, 1659-1692." American Jewish History 91:3-4 (2003): 471-83.

Herzog, Tamar. "Citizenship and Empire: Communal Definition in Eighteenth-Century Spain and Spanish 
America." In Privileges and Rights of Citizenship: Law and the Juridical Construction of Civil Society, edited by Julius Kirshner and Laurent Mayali, 147-168. Berkeley: Robbins Collection, 2002.

. Defining Nations: Immigrants and Citizens in Early Modern Spain and Spanish America. New Haven: Yale University Press, 2003.

Hofmeester, Karin. "Jewish Parliamentary Representatives in the Netherlands, 1848-1914." In Borders and Boundaries in and around Dutch Jewish History, edited by Judith Frishman, et al., 65-80. Amsterdam: Aksant, 2011.

Hollander, J.H. "Documents relating to the Attempted Departure of the Jews from Surinam in 1675." Publications of the American Jewish Historical Society 6 (1897): 9-29.

- "The Naturalization of Jews in the American Colonies under the Act of 1740." Publications of the American Jewish Historical Society 5 (1897): 103-17.

Hurwitz, Samuel J., and Edith Hurwitz. "The New World Sets an Example for the Old: The Jews of Jamaica and Political Rights, 1661-1831." American Jewish Historical Quarterly 55 (1965-66): 37-56.

Huusen, H. "Legislation on the Position of the Jews in the Dutch Republic, c. 1590-1796." Tijdschrift voor Rechtsgeschiedenis/Legal History Review 69 (2001): 43-56.

Hyamson, Albert M. The Sephardim of England: A History of the Spanish and Portuguese Jewish Community, 1492-1951. London: Methuen, 1951.

Israel, Jonathan. "Jews of Dutch America." In The Jews and the Expansion of Europe to the West, 1450-1800, edited by Paolo Bernardini and Norman Fiering, 335-49. New York: Berghahn, 2001.

- "The Jews of Curaçao, New Amsterdam and the Guyanas: A Caribbean and Trans-Atlantic Network (1648-1740)." In Diasporas within a Diaspora: Jews, Crypto-Jews and the World Maritime Empires (1540-1740), edited by Jonathan Israel, 511-32. Leiden: Brill, 2002.

Judah, George Fortunatus. "The Jews' Tribute in Jamaica. Extracted from the Journals of the House of Assembly of Jamaica." Publications of the American Jewish Historical Society 18 (1909): 149-177.

Kaplan, Yosef. "The Curaçao and Amsterdam Jewish Communities in the 17th and 18th Centuries." American Jewish History 72:2 (1982): 193-211.

. "The Formation of the Western Sephardic Diaspora." In The Sephardic Journey, edited by Haham Gaon, 136-55. New York: Yeshiva University Museum, 1992.

Katz, David. The Jews in the History of England, 1485-1850. Oxford: Clarendon Press, 1996.

-. Philo-Semitism and the Readmission of the Jews to England, 1603-1655. Oxford: Clarendon Press, 1982).

—

Kettner, James H. The Development of American Citizenship, 1608-1870. Chapel Hill: University of North Carolina Press/Institute of Early American History and Culture, 1978.

Klooster, Wim. The Dutch in the Americas, 1600-1800: A Narrative History with the Catalogue of an Exhibition of Rare Prints, Maps, and Illustrated Books from the John Carter Brown Library. Providence: The John Carter Brown Library, 1997.

—. "Jews in Suriname and Curaçao." In The Jews and the Expansion of Europe. The Jews and the Expansion of Europe to the West, 1450-1800, edited by Paolo Bernardini and Norman Fiering, 350-68. New York: Berghahn, 2001.

- "Other Netherlands beyond the Sea: Dutch America Between Metropolitan Control and Divergence, 1600-1795." In Negotiated Empires: Centers and Peripheries in the Americas, 1500-1820, edited by Christine Daniels and Michael V. Kennedy, 171-92. New York: Routledge, 2002.

Kohler, Max J. "Civil Status of the Jews in Colonial New York." Publications of the American Jewish Historical Society 6 (1897): 81-106.

Korn, Bertram Wallace. Jews and Negro Slavery in the Old South, 1789-1865. Elkins Park, Penn.: Reform Congregation Keneseth Israel, 1961.

Kuijpers, Erika, and Maarten Prak. "Burger, ingezetene, vreemdeling: burgerschap in Amsterdam in de 17e en 18e eeuw." In Burger: Een geschiedenis van het begrip "burger" in de Nederlanden van de Middeleeuwen tot de 21ste eeuw, edited by Joost Kloek and Karin Tilmans, 113-32. Amsterdam: Amsterdam University Press, 2002.

LaFleur, Gerard. "Les juifs des Antilles françaises sous l'Ancien Régime." Unpublished paper presented at the 44th annual conference of Caribbean Historians, Willemstad, Curaçao 13-18 May 2012.

Lier, R.A.J. van. "The Jewish Community in Surinam: A Historical Survey." In The Jewish Nation in Surinam: Historical Essays, edited by Robert Cohen, 19-27. Amsterdam: S. Emmering, 1982. 
Lipman, Vivian D. "Sephardi and other Jewish Immigrants in England in the Eighteenth Century." In Migration and Settlement: Proceedings of the Anglo-American Jewish Historical Conference Held in London, July 1970, edited by Aubrey Newman, 37-63. London: Jewish Historical Society of England, 1971.

Loker, Zvi. Jews in the Caribbean: Evidence on the History of the Jews in the Caribbean Zone in Colonial Times. Jerusalem: Institute for Research on the Sephardi and Oriental Jewish Heritage, 1991.

Luiten van Zanden, Jan and Maarten Prak. "Towards an Economic Interpretation of Citizenship: The Dutch Republic between Medieval Communes and Modern Nation-States." European Review of Economic History 10 (2006): 111-45.

Maika, Dennis J. "The Burger Right in Seventeenth-Century Manhattan." In Revisiting New Netherland: Perspectives on Early Dutch America, 92-128. Leiden: Brill, 2005.

Marcus, Jacob Rader. The Colonial American Jew: 1492-1776. 3 vols. Detroit: Wayne State University Press, 1970.

Matar, N.I. "The Idea of the Restoration of the Jews in English Protestant Thought, 1661-1701." Harvard Theological Review 78:1-2 (1985): 115-48.

—. "John Locke and the Jews." Journal of Ecclesiastical History 44:1 (1993): 45-62.

Merrill, Gordon. "The Role of Sephardic Jews in the British Caribbean Area during the Seventeenth Century." Caribbean Studies 4:3 (1964): 32-50.

Monaco, C.S. "Port Jews or a People of the Diaspora? A Critique of the Port Jew Concept." Jewish Social Studies: History, Culture, Society 15:2 (2009): 137-66.

Oppenheim, Samuel. "Early History of the Jews in New York, 1654-1664: Some New Matter on the Subject." Publications of the American Jewish Historical Society 18 (1909): 4-37.

—. "More about Jacob Barsimson, the First Jewish Settler in New York." Publications of the American Jewish Historical Society 29 (1925): 39-52.

Perry, Thomas W. Public Opinion, Propaganda, and Politics in Eighteenth-Century England: A Study of the Jew Bill of 1753. Cambridge: Harvard University Press, 1962.

Petitjean-Roget, J. "Les Juifs à la Martinique sous l'ancien Régime.” Revue d'historique des Colonies 43 (1956): 138-58.

Prak, Maarten. "Burghers into Citizens: Urban and National Citizenship in the Netherlands during the Revolutionary Era (c. 1800)." Theory and Society 26:4 (1997): 403-20.

- "The Politics of Intolerance: Citizenship and Religion in the Dutch Republic (Seventeenth to Eighteenth Centuries)." In Calvinism and Religious Toleration in the Dutch Golden Age, edited by R. Po-chia Hsia and Henk van Nierop, 159-75. Cambridge: Cambridge University Press, 2002.

Reijnders, C. Van 'joodsche Natiën'tot Joodse Nederlanders, Een onderzoek naar getto- en assimilatieverschijnselen tussen 1600 en 1942. Amsterdam: JOKO, 1971.

Rens, L.L.E. "Analysis of Annals Relating to Early Jewish Settlement in Surinam." In The Jewish Nation in Surinam: Historical Essays, edited by Robert Cohen, 29-46. Amsterdam: S. Emmering, 1982.

Roitman, Jessica Vance. "New Christians, Jews, and Amsterdam at the Cross-Roads of Expansion Systems." In Migration, Trade, and Slavery in an Expanding World: Essays in Honor of Pieter Emmer, edited by Wim Klooster, 119-40. Leiden: Brill, 2009.

"Sephardic Journeys: Travel, Place, and Conceptions of Identity." Jewish Culture and History 11:1-2 (2009): 209-28.

. Us and Them: Inter-cultural Trade and the Sephardim, 1595-1640. Leiden: Brill, 2011.

Rooden, Peter van. "Jews and Religious Toleration in the Dutch Republic." In Calvinism and Religious Toleration in the Dutch Golden Age, edited by R. Po-chia Hsia and Henk van Nierop, $132-47$. Cambridge: Cambridge University Press, 2002.

Ross, J.M. "The Naturalisation of Jews in England." Jewish Historical Studies 24 (1974): 59-74.

Roth, Cecil. A History of the Jews in England. Oxford: Clarendon Press, 1964.

. The Jews in the Renaissance. Philadelphia: Jewish Publication Society, 1964.

Rowland, Robert. "New Christian, Marrano, Jew." In The Jews and the Expansion of Europe to the West, 1450-1800, edited by Paolo Bernardini and Norman Fiering, 125-48. New York: Berghahn, 2001.

Samuel, Edgar R. "Portuguese Jews in Jacobean London." Transactions of the Jewish Historical Society of England 18 (1958): 171-230.

Schmidle, Erwin A. "Jews in the Austro-Hungarian Armed Forces, 1867-1918." In Studies in Contemporary Jewry: An Annual. Vol. 3, Jews and Other Ethnic Groups in a Multi-ethnic World, 
edited by Ezra Mendelsohn, 127-46. Oxford: Oxford University Press, 1987.

Schorsch, Jonathan. "American Jewish Historians, Colonial Jews and Blacks, and the Limits of Wissenschaft: A Critical Review." Jewish Social Studies 6:2 (2000): 102-32.

. "Jews and Blacks in the Early Colonial World, 1440-1800." Ph.D. diss., University of California, Berkeley, 2000.

The Secret Relationship between Black and Jews. Chicago: Nation of Islam, 1991.

Shapiro, James. Shakespeare and the Jews. New York: Columbia University Press, 1996.

Snyder, Holly. "English Markets, Jewish Merchants, and Atlantic Endeavours: Jews and the Making of British Transatlantic Commercial Culture, 1650-1800." In Atlantic Diasporas: Jews, Conversos, and Crypto-Jews in the Age of Mercantilism, 1500-1800, edited by Richard L. Kagan and Philip D. Morgan, 50-74. Baltimore: Johns Hopkins University Press, 2009.

. "Rules, Rights and Redemption: The Negotiation of Jewish Status in British Atlantic Port Towns, 1740-1831." Jewish History 20:2 (2006): 147-70.

Sombert, Werner. The Jews and Modern Capitalism. 1911. Reprint Kitchener, Ont.: Batoche, 2001.

Tels-Elias, L.J. "De Resolutie van de Staten van Holland van 12 Juli 1657 en de Civiele Status van de Nederlandse Joden." Bijdragen en Mededelingen van het Genootschap voor de Joodsche Wetenschap in Nederland 7 (1960): 56-7.

Tilly, Charles. "Citizenship, Identity and Social History." International Review of Social History 40:3 (1995): 1-17.

Vink, Wieke. Creole Jews: Negotiating Community in Colonial Suriname. Leiden: KITLV Press, 2010.

Vries, Jan de, and Ad van der Woude. The First Modern Economy: Success, Failure, and Perseverance of the Dutch Economy, 1500-1815. Cambridge: Cambridge University Press, 1997.

Wachtel, Nathan. "Marrano Religiosity in Hispanic America in the Seventeenth Century." In The Jews and the Expansion of Europe to the West, 1450-1800, edited by Paolo Bernardini and Norman Fiering, 149-71. New York: Berghahn, 2001.

Weisbord, Robert G., and Arthur Stein. Bittersweet Encounter: The Afro-American and the American Jew. Westport: Greenwood Press, 1970.

Williams, James Homer. "An Atlantic Perspective on the Jewish Struggle for Rights and Opportunities in Brazil, New Netherland, and New York." In The Jews and the Expansion of Europe to the West, 1450-1800, edited by Paolo Bernardini and Norman Fiering, 369-93. New York: Berghahn, 2001.

Wilson, Kathleen. "Introductions: Histories, Empires, Modernities." In A New Imperial History: Culture, Identity and Modernity in Britain and the Empire, 1660-1840, edited by Kathleen Wilson, 1-26. Cambridge: Cambridge University Press, 2004.

Winkler, Karen J. "Group Issues Statement on Role of Jews in Slave Trade." Chronicle of Higher Education, February 17, 1995, A15.

Yerushalmi, Yosef Hayim. "Between Amsterdam and New Amsterdam: The Place of the Curaçao and the Caribbean in Early Modern Jewish History." American Jewish History 72:2 (1982): 172-92. 


\section{Notes}

* This article was written as part of the "Dutch Atlantic Connections, 1680-1800" project sponsored by the Dutch Research Council (NWO). I would like to thank the NWO for making this research possible, and the Royal Dutch Institute for Southeast Asian and Caribbean Studies (KITLV) for hosting me during the duration of my tenure as a postdoctoral researcher working on this project. Professor Dr. Gert Oostindie, Director of the KITLV, read an early draft of this article and gave me invaluable advice and suggestions, as did the two anonymous reviewers. My thanks to them all.

1 Of course, there was a substantial population of "New Christians" or conversos (descendants of Jews converted, forcibly or voluntarily, in Iberia) in the Spanish and Portuguese American territories, many of whom played quite prominent roles in the economic and cultural life of these settlements, but they could not live openly as Jews. In fact, there were tribunals of the Inquisition in Mexico City, Cartagena de las Indias, and Lima committed to prosecuting so-called "Judaizers." See, among others, Rowland, "New Christian, Marrano, Jew;" Wachtel, "Marrano Religiosity in Hispanic America in the Seventeenth Century;" Alberro, "Crypto-Jews and the Mexican Holy Office in the Seventeenth Century," 172-85; Böhm, "Crypto-Jews and New Christians in Colonial Peru and Chile," 203-12; Baião, A Inquisição em Portugal e no Brazil. Subsídios para a sua História; d'Oliveira França and Siquiera, eds., "Segunda visitação do Santo Ofício ás partes do Brasil: Livro das confissões e ratificações da Bahia, 1618-1620;" Gonsalves de Mello, Gente da Nação: Cristãos-novos e judeus em Pernambuco, 1542-1654; Roitman, "Sephardic Journeys: Travel, Place, and Conceptions of Identity," 209-28; and Roitman "New Christians, Jews, and Amsterdam at the Cross-Roads of Expansion Systems," 119-40. In the French Caribbean colonies, Louis XIV's Code Noir led to the expulsion of most Jews from French possessions in the Caribbean and the Guianas. See Arbell, "Jewish Settlements in the French Colonies in the Caribbean (Martinique, Guadeloupe, Haiti, Cayenne) and the "Black Code'," 287-313 and his The Jewish Nation of the Caribbean: The Spanish-Portuguese Jewish Settlement in the Caribbean and the
Guianas; Petitjean-Roget, "Les Juifs à la Martinique sous l'ancien Régime;" and LaFleur, "Les juifs des Antilles françaises sous l'Ancien Régime."

2 The 1707 Act of Union created Britain. In this article, I use "English" when the chronology is clearly before 1707. Likewise, when the chronology under discussion is definitely after the Act of Union, I use the term "British". If I am referring, generally, to the whole period under discussion in this article, I also opt to use "British" instead of "English." "United Kingdom" is commonly used to refer to the post-1801 period, after the Irish Parliament voted to join the Kingdom of Great Britain. Thanks to Dr. Kenneth Morgan of Brunel University who pointed out my misuse of terminology in an earlier version of this paper.

3 Wilson, "Introductions: Histories, Empires, Modernities," 6.

4 This was also the case under Islam under which the majority of Jews in the medieval and early modern world lived. Certain basic inequalities were the norm for dhimmis, second-class citizens who enjoyed certain rights but also many restrictions. See Bell, Jews in the Early Modern World, 209.

5 Kaplan, "The Formation of the Western Sephardic Diaspora," 140.

6 Hyamson, The Sephardim of England, 1-23.

7 Samuel, "Portuguese Jews in Jacobean London," 171-230.

8 The original document is written in French and includes seven requests for Cromwell's council to consider: 1) The general readmission of the Jews as ordinary citizens; 2) a public synagogue and religious toleration; 3 ) the right to their own cemetery; 4) the privilege of trading freely in all sorts of merchandise; 5) the right of Jews to try their cases according to Mosaic law, with appeals to English Civil law; 6) the supervision of the process of readmission by a "person of quality; 7) that any remaining anti-Jewish legislation be repealed. See Katz, The Jews in the History of England, 1485-1850, 116.

9 Katz, Philo-Semitism and the Readmission of the Jews to England, 1603-1655 is the standard work on the subject. Chapter 2 of Endelman's seminal The Jews of Georgian England, 1714-1830 is another standard explication of the subject. See also the collection of essays David Katz co-edited with Jonathan Israel, Sceptics, Millenarians and Jews, which discusses the general intellectual history of scepticism, millenarianism and the role of the Jews in Europe in the seven- 
teenth and eighteenth centuries. Two articles by N.I. Matar, "The Idea of the Restoration of the Jews in English Protestant Thought, 1661-1701" and "John Locke and the Jews," contextualise the arguments for readmitting and integrating Jews into English society. Matt Goldish has edited a volume on Jewish Messianism in the Early Modern World which discusses some of these same general trends.

10 Chapter 3 of Katz, The Jews in the History of England, explores the events surrounding the Whitehall Conference in great depth.

11 For example, in 1702 an act was passed to encourage conversions to Protestantism and there were certain short-lived discriminatory tax laws and proposals in the reign of William and Mary. See Roth, A History of the Jews in England, 187.

12 Endelman, The Jews of Georgian England, 20-6, and Herzog, Defining Nations: Immigrants and Citizens in Early Modern Spain and Spanish America, 178-84. They could, however, engage in wholesale trade.

13 Endelman, The Jews of Georgian England, 22. The alderman presented petitions to increase the number of Jewish brokers in 1723, 1730 and 1739, to no avail.

14 Lipman, "Sephardi and Other Jewish Immigrants in England in the Eighteenth Century," 37-63.

15 The alien duties were repealed in 1784 . See Perry, Public Opinion, 14.

16 This was changed by an act of Parliament in 1698 (11 Will. 3 c. 6) which enabled any natural-born subject of the Crown to inherit through or from an ancestor born abroad. Henceforth, an endenized foreigner could pass on his property to his heirs, with the only remaining disability being that he, himself, could not inherit. See Ross, "The Naturalisation of Jews in England," 59-74.

17 Perry, Public Opinion, 15-16. Around 150 Jews were made denizens between 1660 and 1700. See Barnett, ed., Bevis Marks Records, vol. 1; and Roth, A History of the Jews in England, 212.

18 Ross, "The Naturalisation of Jews in England."

19 Webb, The Question whether a Jew born within the British Dominions could before the late Act purchase and hold Lands. By a Gentleman of Lincoln's Inn (1753), 38.

20 Ross, "The Naturalisation of Jews in England."

21 Ibid.

22 Shapiro, Shakespeare and the Jews, 181.
2313 George II, c. 7 (1740). This was known as the "Plantation Act."

24 Hollander, "The Naturalization of Jews in the American Colonies under the Act of 1740," 104-5.

25 In sections II and III of the statute, "such as who profess the Jewish Religion" are specifically exempted from the necessity of receiving the sacrament as a qualification for naturalisation; in the latter the same persons are allowed to omit the phrase "upon the true faith of a Christian" in taking the oath of abjuration. 13 George II, c. 7 (1740).

26 Snyder, "Rules, Rights and Redemption," 151, and Hurwitz and Hurwitz, "The New World Sets an Example for the Old," 37-56.

27 Luiten van Zanden and Prak, "Towards an Economic Interpretation of Citizenship," 121, 140.

28 Kuijpers and Prak, "Burger, ingezetene, vreemdeling," 115.

29 Luiten van Zanden and Prak, "Towards an Economic Interpretation of Citizenship," 122.

30 Kuijpers and Prak, "Burger, ingezetene, vreemdeling," 116.

31 De Vries and Van der Woude, The First Modern Economy, 654-64, Prak, "Burghers into Citizens," 407.

32 Luiten van Zanden and Prak, "Towards an Economic Interpretation of Citizenship," 124.

33 Fuks-Mansfeld, De Sefardim van Amsterdam tot 1795, 58.

34 De la Court, Interest van Holland oft Gronden van Hollands Welvaren, 38.

35 The historian Pieter van Rooden believes that Jews were allowed to maintain such a public presence in the Dutch Republic because they were not Christians and did not challenge the legitimacy of Calvinism as a state religion. This was in contrast to Catholics and other Protestant sects, who had to worship in schuilkerken-churches that were not recognisable as such. See van Rooden, "Jews and Religious Toleration in the Dutch Republic," 141-2.

36 Ibid., 142.

37 Nevertheless, Jews were not entirely banned from guild membership in Amsterdam. The brokers, pharmacists, surgeons, and booksellers' guilds allowed limited numbers of Jews membership. See Frank and Brugmans, Geschiedenis der Joden in Nederland, 577.

38 It is not clear if, in practice, Jews actually were required to purchase citizenship for their children. See Reijnders, Van "joodsche Natiën" tot Joodse Nederlanders, 24; Fuks-Mansfeld, De sefardim in Amsterdam tot 1795, 70; 
Prak, "The Politics of Intolerance," 171. This was also the case for women. See Kuijpers and Prak, "Burger, ingezetene, vreemdeling," 120.

39 Katz, The Jews in the History of England, 157.

40 Van Rooden, "Jews and Religious Toleration in the Dutch Republic," 140.

41 Cobbett, Parliamentary History of England from the Earliest Period to the Year 1803, vol. 14: 1380

42 Verslag der Handelingen van de Tweede Kamer der Staten-Generaal, meeting of 6 December 1873, 621. Quoted in Hofmeester, "Jewish Parliamentary Representatives in the Netherlands, 1848-1914," 74.

43 Tilly, "Citizenship, Identity and Social History," 7-8.

44 Ibid.

45 Felsenstein, Anti-Semitic Stereotypes, 3.

46 Corte ende waerachtighe beschrijuinge van eenen jode, ghenaemt: Asverus of Wandelende jood.

47 There were many rarekieks published in the seventeenth and eighteenh centuries. A rarekiek was a sort of popular vignette employed to give readers a glimpse of wellknown people, events, or exotic beings such as the Jews. See De hoogduitsche Jood, met zyn politieke rarekiek-kas, die hy van zyn vader geerft heft (place of publication unknown, 1675).

48 Prak, "Burghers into Citizens," 407.

49 Luiten van Zanden and Prak, "Towards an Economic Interpretation of Citizenship," 122.

50 The term "subject" [onderdaan] was not a popular term in the Dutch Republic due to its association with absolutist monarchies such as the Habsburgs against whom the Dutch Republic had rebelled. Therefore, the term was mostly used in correspondence with foreign governments. Within the Republic, various terms, usually denoting municipal affiliation, such as "burgers," "poorters" and "ingezetenen" were employed instead. See Van den Berg, "Inboorlingschap en Ingezetenschap in de Republiek der Verenigde Nederlanden, 1600-1795,” 131.

51 For Barbados, see Fortune, Merchants and Jews: The Struggle for British West Indian Commerce, 1650-1750, 41, 45-6, 103-4; Davis, "Notes on the History of the Jews in Barbados," 129-48; Arbell, The Jewish Nation of the Caribbean, 203-10. For more on Suriname, see Arbell, The Jewish Nation of the Caribbean, 97-104; Vink, Creole Jews: Negotiating Community in Colonial
Suriname, 87-99; Nassy, Historical Essay on the Colony of Surinam 1788, 103. For the North American colonies, Kettner, The Development of American Citizenship, 1608-1870, 114-7.

52 The Jews in Dutch Brazil enjoyed unprecedented and, until that point, wholly unique economic and religious freedoms and concomitant favourable legal status. Nevertheless, as Jonathan Israel notes, the success and vigour of Jewish society in the Dutch colony, lasting from only 1633-45 (from which point it was, for all intents and purposes, undermined), was transitory. See Israel, "Jews of Dutch America," 342. Therefore, drawing examples from other, longer-lasting, Dutch Atlantic settlements, allowing for a more consistent comparison with the British Atlantic territories, seemed to be a sensible choice.

53 Merrill, "The Role of Sephardic Jews in the British Caribbean Area during the Seventeenth Century," 32-50.

54 Sainsbury, ed., "America and West Indies: December 1670," no. 367. A suggestion to this effect had previously been made (Sept. 20, 1670) by Sir Thomas Modyford. See Sainsbury, ed., "America and West Indies: September 1670, 16-30," no. 264.

55 Sainsbury, ed., "America and West Indies: July 1672," no. 879.

56 Long, The History of Jamaica, vol. 2: 18.

57 Headlam and Newton, eds., "America and West Indies: April 1733, 16-30," vol. 40: 1733.

58 Godfrey and Godfrey, Search Out the Land: The Jews and the Growth of Equality in British Colonial America, 1740-1867, 55.

59 For a discussion of this case, see Kettner, The Development of American Citizenship, 116-7. Kettner places this rejection of the request for naturalisation within the context of larger internecine political conflicts within the colony.

60 Quoted in Snyder, "English Markets, Jewish Merchants, and Atlantic Endeavours," 56.

61 Kettner, The Development of American Citizenship, 117.

62 Shapiro, Shakespeare and the Jews, 207.

63 Snyder, "Rules, Rights and Redemption," 156.

64 Dubin, "Introduction: Port Jews in the Atlantic World," 123.

65 Long, History of Jamaica, vol. 2: 18. See also Monaco, "Port Jews or a People of the Diaspora?”, 89.

66 As Jonathan Schorsch notes, this identifica- 
tion as "white" was not a given. Both Jews and non-Jews during the early colonial era were ambivalent about the "racial" status of Jews, especially in Northern European contexts. For example, in 1691 FrancoisMaximilian Mission, one of the influences for Buffon's Natural History, wrote against such views of Jewish blackness while holstering in the process the impression that the idea was not uncommon: "Tis also a vulgar error that the jews are all black; for this is only true of the Portuguese, who, marrying always among one another, beget Children like themselves, and consequently the Swarthiness of their complexion is entail'd upon their whole Race, even in the Northern Regions." Mission, A New Voyage to Italy, vol. 2: 139, cited by Gilman, The Visibility of the Jew in the Diaspora, 3, quoted in Schorsch, "American Jewish Historians, Colonial Jews and Blacks, and the Limits of Wissenschaft," 129.

67 Drescher, "Jews and New Christians in the Atlantic Slave Trade," 452. Eli Faber estimates that Jews purchased 7.1 per cent of the slaves landed by the Royal African Company in Jamaica between 1674 and 1700. See Faber, Jews, Slaves and the Slave Trade, 54-5. Trevor Burnard arrives at a similar figure of 6.5 per cent for the period 1674-1708; see Burnard, "Who Bought Slaves in Early America?", 68-92. See also Fortune, Merchants and Jews, 48.

68 Faber, Jews, Slaves, and the Slave Trade, 24-30.

69 Ibid.

70 In the third quarter of the eighteenth century, the Sephardic Jewish slaving house of Rivera and Lopez in Newport, Rhode Island, accounted for 9 per cent of that colony's slaving activities. In Jamaica, the aftershocks of the American Revolution led to a brief resurgence in the slave trade, including among Jews. In the late 1780 s, 26.7 per cent of reexported slaves were carried on Jewishowned vessels. Drescher, "Jews and New Christians in the Atlantic Slave Trade," 454. There was also a brief boom in Jewish factors for the slave trade. In the mid-1790s, the Jewish Christian partnership of Alexandre Lindo and Richard Lake was responsible for between 22 and 37 per cent of all slaves advertised for sale in Kingston, Jamaica. See Faber, Jews, Slaves, and the Slave Trade, 73-82, 113-23.

71 In 1991, the Historical Research Department of the Nation of Islam published The Secret Relationship between Black and Jews
(Chicago: Nation of Islam, 1991), which asserted that Jews had dominated the trade in slaves. This led the Council of the American Historical Association (AHA) to adopt a resolution calling "false any statement alleging that Jews played a disproportionate role in the exploitation of slave labour or in the Atlantic slave trade." On the origins of the statement by the AHA, see Winkler, "Group Issues Statement on Role of Jews in Slave Trade." There followed a huge number of refutations of the Nation of Islam's claims, including Eli Faber, Jews, Slaves and the Slave Trade; David Brion Davis, "The Slave Trade and the Jews," New York Review of Books, December 22, 1994, 14-16; Seymour Drescher, "The Role of Jews in the Transatlantic Slave Trade," Immigrants and Minorities 12 (1993): 113-25.

72 Sombert, The Jews and Modern Capitalism; Roth, The Jews in the Renaissance; Marcus, The Colonial American Jew: 1492-1776, 1; Yerushalmi, "Between Amsterdam and New Amsterdam," 172-92; Baron, A Social and Religious History of the Jews, vol. 15; Schorsch, "Jews and Blacks in the Early Colonial World, 1440-1800,"; Korn, Jews and Negro Slavery in the Old South, 1789-1865; Diner, In the Almost Promised Land; Weisbord and Stein, Bittersweet Encounter. See also Brackman, "The Ebb and Flow of Conflict."

73 Fortune, Merchants and Jews, 11-12; See also Faber, Jews, Slaves and the Slave Trade, 102.

74 Ibid.

75 Monaco, "Port Jews or a People of the Diaspora?", 155.

76 Ibid.

77 Felsenstein, Anti-Semitic Stereotypes, chap. 8; Perry, Public Opinion; Shapiro, Shakespeare and the Jews, chap. 7; Endelman, The Jews of Georgian England, 24-6, 32-33, 36-9, 59-64, 88-91; and Katz, The Jews in the History of England, chap. 6.

78 Perry, Public Opinion, 13-14; and Henriques, The Jews and English Law, 230.

79 Felsenstein, Anti-Semitic Stereotypes, 47.

80 Archaicus [pseud.], Admonitions from Scripture and History, 29.

81 For a detailed discussion of the continued efforts to restrict Jewish participation in colonial life on Jamaica, as well as the frequent attempts to extort money from the Jewish settlers, see Judah, “The Jews' Tribute in Jamaica. Extracted from the Journals of the House of Assembly of Jamaica," 149-77. N. 
Darnell Davis mention similar restrictions in his "Notes on the History of the Jews in Barbados," 133.

82 Acts of Assembly, passed in the island of Jamaica; from 1681 to 1737, inclusive (1743), 68.

83 For reference to the "limited freedom" of Jews and free blacks, see Long, History of Jamaica, vol. 2: 321.

84 Long, History of Jamaica, vol. 2: 293.

85 Snyder, "Rules, Rights and Redemption," 153-154.

86 Herzog, "Citizenship and Empire," 156.

87 The Case of the Jews Stated (1689), 44-6.

88 Quoted in Katz, The Jews in the History of England, 164.

89 Van den Berg, "Inboorlingschap en Ingezetenschap in de Republiek der Verenigde Nederlanden." Van den Berg describes the various procedures available for naturalising within the various provinces, including the various degrees of belonging such as "native," "inhabitant" and "alien."

90 Staten Van Holland, GPB (The Hague, 1770), vol. 7: 59. Staten-Generaal, GPB, vol. 7: 60. The Jews were declared by these two governing entities to be "waarlyk zyn onderdaanen" (truly their subjects). See also Tels-Elias, "De Resolutie van de Staten van Holland van 12 Juli 1657 en de Civiele Status van de Nederlandse Joden," 56-7.

91 Resolutien van de Heeren Ridderschap, Edelen ende Gedeputeerden van de Steden van Hollandt ende West Vrieslandt...1619. See also Huusen, "Legislation on the Position of the Jews in the Dutch Republic, c. 1590 1796," 50.

92 Nationaal Archief, Den Haag (NL-HaNa), Tweede West-Indische Compagnie (WIC), 1.05.01.02/201, 385v.

93 Yerushalmi, "Between Amsterdam and New Amsterdam," 190.

94 Nassy, Historical Essay on the Colony of Surinam 1788, 136.

95 This is not to say that these rights and privileges were not sometimes strongly threatened and, as was the case throughout the Atlantic world, there were countless instances of the Suriname Jewish community appealing to the Amsterdam community to lobby on their behalf for the maintenance of their rights. See Cohen, Jews in Another Environment, 124-44.

96 Vink, Creole Jews, 88.

97 Van Lier, "The Jewish Community in Surinam: A Historical Survey," 21.

98 Arbell, The Jewish Nation of the Caribbean,
176.

99 Williams, "An Atlantic Perspective on the Jewish Struggle for Rights and Opportunities in Brazil, New Netherland, and New York," 369.

100 Kaplan, "The Curaçao and Amsterdam Jewish Communities in the 17th and 18th Centuries," 203.

101 Klooster, The Dutch in the Americas, 1600-1800, 68.

102 There had been problems with WIC official even earlier, in the latter part of the seventeenth century. Balthazar Beck, brother of Governor Mathias Beck, served as slave commissioner on Curaçao. He imprisoned business rival Moseh Henriquez Coutinho based on the testimony of two slaves. When Coutinho's father in Amsterdam took the matter before the WIC directors, Coutinho was freed. NL-HaNA, WIC, 1.05.01.02/336, $11 \mathrm{v}, 190 \mathrm{v}, 343 \mathrm{v}, 383 \mathrm{v}$. This incident is also discussed in Emmanuel and Emmanuel, History of the Jews of the Netherlands Antilles, vol. 1: 84.

103 NL-HaNA, WIC, 1.05.01.02/70, 8v-99; 1.05.01.02/205, 36v, 80v-81v, 125, 501. See also Emmanuel and Emmanuel, History of the Jews of the Netherlands Antilles, 106. The governor was Jeremias van Collen and the tax was levied to pay off the French pirate Jacques Cassard.

104 NL-HaNA, WIC, 1.05.01.02/206,149v.

105 Emmanuel and Emmanuel, History of the Jews of the Netherlands Antilles, 112.

106 Ibid., 133. Smonches is presumably a derivation of smous, a popular pejorative for Jews in the eighteenth-century Netherlands, though it was usually applied to Ashkenazim, not Sephardim.

107 NL-HaNA, WIC, 1.05.01.02/ 579, 39.

108 Emmanuel and Emmanuel, History of the Jews of the Netherlands Antilles, 277.

109 Klooster, "Jews in Suriname and Curaçao," 353, 355.

110 NL-HaNA, WIC, 1.05.01.02/521v-22.

111 Ibid.

112 Ibid.; see also Emmanuel and Emmanuel, History of the Jews of the Netherlands Antilles, 142.

113 WIC, 1.05.01.02.583, 295; Emmanuel and Emmanuel, History of the Jews of the Netherlands Antilles, 141.

114 Klooster, "Other Netherlands Beyond the Sea," 184.

115 In their meetings of July 17, 1657, and September 24, 1658, the States General of Holland recognised the Jews as Dutch citi- 
zens and defended them as such when the Jews were captured at sea by the Spaniards. See NL-HaNA, Staten-Generaal, 1.01.02/142, 225 and 146, 322.

116 NL-HaNA, Staten-Generaal, 1.01.02/129, 29.

117 Many cargoes were co-owned by nonJewish Dutch and/or Flemish merchants. See Roitman, Us and Them: Inter-cultural Trade and the Sephardim, 1595-1640.

118 Sainsbury, ed., "America and West Indies: List of Colonial Entry Books."

119 Rens, "Analysis of Annals Relating to Early Jewish Settlement in Surinam," 29-46.

120 Hollander, "Documents relating to the Attempted Departure of the Jews from Surinam in 1675," 9.

121 The States General would always argue that Jews were Dutch nationals when they and/or their cargoes were captured. The archives of the States General and the Jewish communities of Amsterdam and Curaçao are full of such cases-far too many to elaborate upon in this paper. To take just a few examples, on October 29, 1764, two merchants from Curaçao, Abraham Pinedo and Manuel Taboada, were captured on their way to Caracas and brought as prisoners to Cadiz. They were liberated by July 24, 1765, after the States General exerted extensive pressure on their behalf. Amsterdam Municipal Archive (SAA) 334 /94, 20-21, 73. On April 29, 1766, there was an appeal to the Dutch Ambassador in Madrid, F. Doublet, to act in favour of the release of two Jewish residents of Surinam who had been arrested and taken to Spain while engaged in coastal trade between Porto Belo and Cartagena. This case lasted for nearly four years. SAA, 334/118-119, 360-1.

122 The case of the ship Experiment is welldocumented. David Katz discusses it in his typically exhaustive detail in The Jews in the History of England, 146-9. See also Shapiro, Shakespeare and the Jews, 191 and Snyder, "English Markets," 55. My discussion of the case is drawn from these works.

123 Hayne, An Abstract of All the Statutes Made Concerning Aliens Trading in England... Proving that the Jews...Break Them All.

124 Sainsbury, ed., "America and West Indies: November 1672," and Sainsbury, ed., "America and West Indies: December 1672." See also Friedenwald, "Material for the History of the Jews in the British West Indies," 61-2, 45-101, 80-7.

125 Ibid.

126 Loker, Jews in the Caribbean: Evidence on the History of the Jews in the Caribbean Zone in Colonial Times, 141-8.

127 Nassy, Historical Essay on the Colony of Surinam 1788, 18.

128 Ibid., 230.

129 Stuyvesant to the Amsterdam chamber of the WIC, 30 October 1655, in Oppenheim, "Early History of the Jews in New York, 1654-1664: Some new matter on the subject," 20.

130 Williams, "An Atlantic Perspective," 384. It is somewhat ironic that the Jews and Dutch are so often lumped together by the British, especially regarding smuggling.

131 Williams, "An Atlantic Perspective," 370.

132 For more information on Levy, see Hershkowitz, "Dutch Notarial Records Pertaining to Asser Levy, 1659-1692," 471-83.

133 Fernow, ed., The Records of New Amsterdam from 1653 to 1674, vol. 2: 41.

134 Loker, Jews in the Caribbean, 141.

135 Ibid.

136 Ibid., 142.

137 Ibid., 146.

138 Ibid., 147.

139 Williams, "An Atlantic Perspective," 380.

140 Asser Levy has been discussed in multiple sources. See Williams, "An Atlantic Perspective," 383. Holly Snyder's discussion of Levy in "English Markets" moves beyond the issue of citizenship and takes an interesting look at his economic activities.

141 O'Callaghan, ed., Laws and Ordinances of New Netherland, 1638-1674, 191-2.

142 For more information on Barsimson, see Oppenheim, "More about Jacob Barsimson, the First Jewish Settler in New York," 39-52.

143 Luiten van Zanden and Prak, "Towards an Economic Interpretation of Citizenship," 123.

144 Fernow, ed., The Records of New Amsterdam from 1653 to 1674, vol. 7, 31.

145 Maika, "The Burger Right in SeventeenthCentury Manhattan," 95.

146 Kohler, "Civil Status of the Jews in Colonial New York," 81-106, 87-8.

147 Ibid.

148 Maika, "The Burger Right in SeventeenthCentury Manhattan," 97.

149 Klooster, "Other Netherlands Beyond the Sea," 184. 
150 Ibid.

151 Nassy, Historical Essay, 13.

152 NL-HaNA, WIC, 1.05.01.02/585, 608v-28. He was not successful in his attempts to exclude Jews because such a high percentage of the white male population on the island was Jewish. To have excluded Jews would have left the militia in a dangerously weak position. In 1748, of the 175 residents serving in the guard, 44 were Jews. NLHaNA, WIC, 1.05.01.02/210, 55-76.

153 For instance, "Aan de Cornetsbaij anders Maripompoen Lagen omtrend 40 Israeliten op een hogge berg gecampeert onder commando van Mordochaij Henriquez als capitijn, hebbnde tot haar verchansingen eenige broot en meelvate met steenen en gront gevult, egter door de hoogte van de bergh waren genoegzaam schoot vrij voor't canon van passeerende scheepen." This account is confirmed in a letter written by Governor van Collen to the WIC directors, in which he lists "40 Israeliten" serving on the Cornetsbaai. See De Gaaij Fortman, "Een Belangrijk Dagboek," 247 and 249.

154 Jews did not serve in the civil militia in Amsterdam. One issue surrounding the emancipation of Jews in nineteenth-century Europe centred on the perceived unsuitability of Jews for military service, which was considered a precondition for being a fullyfledged citizen. Jews were considered too physically weak, cowardly, and "degenerate." Moreover, the strictures of the Jewish religion, including the Saturday Sabbath and dietary restrictions were commonly used as reasons to exclude Jews from military service. For discussions of Jews and military service see Schmidle, "Jews in the Austro-Hungarian Armed Forces, 1867-
1918," 127-46. For a discussion of some of the issues surrounding Jewish military service and emancipation, see Berkovitz, The Shaping of Jewish Identity in Nineteenthcentury France. For an interesting general exploration of the importance of the military for a sense of national identity in England, see Gould, "To Strengthen the King's Hands," 329-48. Jordana Dym offers an interesting contextualisation of the importance of the civil militias in the Spanish American colonies for the assertion of rights for marginalised groups such as mestizos in her "Policing Nueva Guatemala: The Alcaldes de Barrio Controversy, 1761-1821," unpublished paper presented at the Eight International Conference on Urban History, Stockholm 20 August2 September 2006.

155 NL-HaNA, WIC, 1.05.01.02/357,15.

156 Nassy, Historical Essay, 196-197.

157 Faber, Jews, Slaves, and the Slave Trade, 61.

158 Katz, The Jews in the History of England, 146-9, and Snyder, "English Markets," 55.

159 Israel, "The Jews of Curaçao, New Amsterdam and the Guyanas," 525.

160 See, for example, Hastings, The Construction of Nationhood: Ethnicity, Religion and Nationalism.

161 Anderson, Imagined Communities.

162 Herzog, "Citizenship and Empire," 148.

163 Ibid., 147.

164 Benton, Legal Regimes and Colonial Cultures, 13.

165 Ibid., 25.

166 Romaine, An Answer to a Pamphlet, 10.

167 Hartsinck, Beschrijuing van Guyana of de Wilde Kust in Zuid Amerika, vol. 2: 817. 